\title{
OPTIMIZATION OF THE LOUVER FIN-AND-TUBE HEAT EXCHANGERS-A PARAMETRIC APPROACH
}

\author{
Ali Sadeghianjahromi, ${ }^{1, *}$ Saeid Kheradmand, ${ }^{2}$ \\ Hossain Nemati, ${ }^{3}$ \& Chi-Chuan Wang ${ }^{1, *}$
}

${ }^{1}$ Department of Mechanical Engineering, National Chiao Tung University, 1001 University Road, Hsinchu 300, Taiwan

${ }^{2}$ Department of Mechanical and Aerospace Engineering, Malek-Ashtar University of Technology, Shahin Shahr, P.O. Box 83145/115, Isfahan, Iran

${ }^{3}$ Department of Mechanics, Marvdasht Branch, Islamic Azad University, Marvdasht, Iran

*Address all correspondence to: Ali Sadeghianjahromi, Department of Mechanical Engineering, National Chiao Tung University, 1001 University Road, Hsinchu 300, Taiwan, E-mail: asadeghi63@yahoo.com; and Chi-Chuan Wang, Department of Mechanical Engineering, National Chiao Tung University, 1001 University Road, Hsinchu 300, Taiwan; Tel.: +88 635712121 55105; Fax: +88 635720 634,

E-mail: ccwang@nctu.edu.tw

Original Manuscript Submitted: 1/12/2020; Final Draft Received: 3/9/2020

$3 D$ turbulent flow numerical simulations are performed to study heat transfer and flow friction characteristics of louver fin-and-tube heat exchangers. The effects of louver angle, fin pitch, transversal tube pitch, and longitudinal tube pitch on Colburn and friction factors are investigated in detail. Three stages of the effect of louver angle on the Colburn $j$ factor are identified, including rising, level-off, and increasing again. A wide range for louver angle ranging from $0^{\circ}$ (plain fin) to $80^{\circ}$ is considered. Results show that the Colburn factor increases from a louver angle of $0^{\circ}$ (plain fin) to $20^{\circ}$, followed by a level-off or slight decline until the louver angle reaches $45^{\circ}$, and finally, the Colburn factor is increased again with a further rise of louver angle. However, the friction factor increases with an increase in louver angle from $0^{\circ}$ (plain fin) to $80^{\circ}$. Colburn and friction factors are almost independent of fin pitch while they decrease with an increase in transversal and longitudinal tube pitches. The optimum louver angle is around $20^{\circ}$ upon carrying out the full factorial method in maximizing Colburn factor and minimizing friction factor.

KEY WORDS: heat transfer enhancement, louver fin-and-tube heat exchanger, louver angle, fin pitch, tube pitch, numerical simulation

\section{INTRODUCTION}

A heat exchanger is a device for carting out heat exchange between two fluids in different temperatures. Air-cooled heat exchangers, containing hot fluid and air flow inside and outside of tubes, respectively, are widely used in refrigeration, air conditioning systems, and automobiles. Fins are usually required on the air side of these types of heat exchangers because the heat transfer coefficient of air is extremely low. Either flat, wavy, or louver fins can be adopted as fin surfaces 


\section{NOMENCLATURE}

$\begin{array}{ll}A_{c} & \text { flow cross-sectional area }\left(\mathrm{m}^{2}\right) \\ A_{f} & \text { fin surface area }\left(\mathrm{m}^{2}\right) \\ A_{o} & \text { total heat transfer area }\left(\mathrm{m}^{2}\right) \\ C & \text { heat capacity }(\mathrm{J} / \mathrm{kg} \cdot \mathrm{K}) \\ D_{c} & \text { tube collar outside diameter }(\mathrm{mm}) \\ & \text { (m shall be used in equations) } \\ f & \text { friction factor } \\ F_{p} & \text { fin pitch }(\mathrm{mm}) \\ G & \text { air mass flux }\left(\mathrm{kg} / \mathrm{m}^{2} \cdot \mathrm{s}\right) \\ G_{k} & \text { turbulent kinetic energy generation } \\ & \text { caused by mean velocity } \\ & \text { gradients }(\mathrm{J} / \mathrm{kg}) \\ h & \text { heat transfer coefficient }\left(\mathrm{W} / \mathrm{m}^{2} \cdot \mathrm{K}\right) \\ j & \text { Colburn factor } \\ k & \text { turbulent kinetic energy }(\mathrm{J} / \mathrm{kg}) \\ k_{f} & \text { fluid thermal conductivity }(\mathrm{W} / \mathrm{m} \cdot \mathrm{K}) \\ k_{f i n} & \text { fin thermal conductivity }(\mathrm{W} / \mathrm{m} \cdot \mathrm{K}) \\ K_{c} & \text { entrance loss coefficients } \\ K_{e} & \text { exit loss coefficients } \\ L & \text { length of louver region }(\mathrm{mm}) \\ m & \text { thermo geometry parameter }\left(\mathrm{m}{ }^{-1}\right) \\ N & \text { number of tube rows } \\ N_{l} & \text { number of louvers } \\ \mathrm{Nu} & \text { Nusselt number } \\ P & \text { pressure }(\text { Pa) } \\ P_{l} & \text { longitudinal tube pitch }(\mathrm{mm}) \\ P_{t} & \text { transversal tube pitch }(\mathrm{mm}) \\ \mathrm{Pr} & \text { Prandtl number } \\ \dot{Q}^{\prime \prime} & \text { heat transfer rate to the fluid } \\ & \text { per surfaces area }\left(\mathrm{W} / \mathrm{m}^{2}\right) \\ r & \text { tube radius }(\mathrm{m}) \\ r_{f} & \text { equivalent circular fin radius }(\mathrm{m}) \\ \mathrm{Re} D_{D_{c}} & \text { Reynolds number based on tube } \\ & \text { collar outside diameter } \\ & \end{array}$

$\begin{array}{ll}\text { St } & \text { Stanton number } \\ T & \text { temperature }(\mathrm{K}) \\ t & \text { fin thickness }(\mathrm{mm}) \\ u & \text { velocity }(\mathrm{m} / \mathrm{s}) \\ W & \text { width of louver } \\ & \text { region }(\mathrm{mm}) \\ Y^{+} & \text {Y plus }\end{array}$

Greek Symbols

$\alpha_{k} \quad$ inverse turbulent Prandtl numbers for $k$

$\alpha_{\varepsilon} \quad$ inverse turbulent Prandtl numbers for $\varepsilon$

$\Delta P \quad$ pressure drop $(\mathrm{Pa})$

$\Delta T_{l m} \quad$ logarithmic mean temperature difference $(\mathrm{K})$

$\varepsilon \quad$ dissipation rate $\left(\mathrm{m}^{2} / \mathrm{s}^{3}\right)$

$\eta \quad$ fin efficiency

$\eta_{o} \quad$ surface efficiency

$\theta \quad$ louver angle (degree)

$\mu \quad$ dynamic viscosity $(\mathrm{kg} / \mathrm{m} \cdot \mathrm{s})$

$\mu_{t} \quad$ turbulent dynamic

viscosity $(\mathrm{kg} / \mathrm{m} \cdot \mathrm{s})$

$\rho \quad$ density $\left(\mathrm{kg} / \mathrm{m}^{3}\right)$

$\sigma \quad$ minimum to frontal

flow area ratio

$\psi \quad$ fin efficiency parameter

\begin{tabular}{ll}
\multicolumn{2}{l}{ Subscripts } \\
$i, j, k$ & tensor index \\
in & inlet \\
$m$ & mean \\
out & outlet \\
$s$ & solid wall
\end{tabular}

to remedy the poor performance of air in typical air-cooled heat exchangers. By employing the periodic boundary-layer renewal, the heat transfer coefficients (HTCs) in louver fins are much higher than flat and wavy fins, and it also comes with the price of an appreciable pressure drop penalty. The presence of louvers not only offers boundary layer restarting for heat transfer enhancement but also provides sufficient airflow mixing. The louvers are formed by punching the metal and are protruded out from the base metal (Shah and Sekulic, 2003). Although wide 
studies on flat, wavy, and slit fins can be found in the literature (Awad and Muzychka, 2011; Glazar et al., 2012; Jang and Yang, 1998; Jiao and Baek, 2005; Kim and Cho, 2015; Kim and Youn, 2013; Lin et al., 2008; Sadeghianjahromi et al., 2018b, 2020; Taler, 2004; Tao et al., 2007; Wang et al., 1996, 1999, 2000), louver fins still attract a lot of attention for further optimization from the aspects of experimental and numerical investigations, Kays and London (1950) were the first, who summarized experimental results related to louver fins. The first paper regarding two-dimensional numerical simulations on louver fins was prepared by Baldwin et al. (1987). Some recent experimental and numerical studies on louver fins including their major conclusions are summarized in Table 1.

TABLE 1: Recent experimental and numerical studies on louver fins

\begin{tabular}{|c|c|c|c|}
\hline No. & Research & $\begin{array}{l}\text { Research type/ } \\
\text { Tube type }\end{array}$ & Major conclusions \\
\hline 1 & $\begin{array}{l}\text { Achaichia } \\
\text { and Cowell } \\
\quad(1988)\end{array}$ & $\begin{array}{c}\text { Experimental/ } \\
\text { Flat }\end{array}$ & $\begin{array}{l}\text { 1. This paper was the first publication for louver } \\
\text { fin-and-flat tube heat exchangers. } \\
\text { 2. Flow is duct flow in low Re. } \\
\text { 3. Correlations were developed for St and } f \text {. }\end{array}$ \\
\hline 2 & $\begin{array}{l}\text { Pauley and } \\
\text { Hodgson } \\
\text { (1994) }\end{array}$ & $\begin{array}{c}\text { Experimental/ } \\
\text { No tube }\end{array}$ & $\begin{array}{l}\text { 1. Flow visualization was performed using dye } \\
\text { injection. } \\
\text { 2. The mixing angle increases with rise in Re. } \\
\text { 3. The larger } \theta \text { causes mixing angle to be larger. }\end{array}$ \\
\hline 3 & $\begin{array}{l}\text { Cowell } \\
\text { et al. (1995) }\end{array}$ & $\begin{array}{l}\text { Experimental/ } \\
\text { Flat }\end{array}$ & $\begin{array}{l}\text { 1. Operating mechanisms in multilouver fins were } \\
\text { discussed. } \\
\text { 2. Louver fins are suitable for applications with } \\
\text { smaller size, less weight, and lower pumping power. }\end{array}$ \\
\hline 4 & $\begin{array}{l}\text { Atkinsona } \\
\text { et al. (1998) }\end{array}$ & Numerical/Flat & $\begin{array}{l}\text { 1. 2D and 3D numerical simulations were discussed. } \\
\text { 2. Both 2D and 3D models predict pressure losses } \\
\text { accurately, while 3D models predict heat transfer } \\
\text { higher than 2D models. }\end{array}$ \\
\hline 5 & $\begin{array}{l}\text { Wang et al. } \\
\text { (1998a) }\end{array}$ & $\begin{array}{l}\text { Experimental/ } \\
\text { Circular }\end{array}$ & \begin{tabular}{|l} 
1. $\quad N$ has negligible effect on $f$. \\
2. Effect of $F_{p}$ on $h$ is insignificant for $\operatorname{Re}_{D_{c}}>2000$. \\
3. Correlations for $j$ and $f$ factors were developed.
\end{tabular} \\
\hline 6 & $\begin{array}{l}\text { Leu et al. } \\
\text { (2001) }\end{array}$ & $\begin{array}{l}\text { Numerical/ } \\
\text { Circular and oval }\end{array}$ & $\begin{array}{l}\text { 1. } 10 \% \text { and } 41 \% \text { decrease in } h \text { and } \Delta P \text { are obtained, } \\
\text { respectively by using oval tube instead of circular tube. } \\
\text { 2. Both } h \text { and } \Delta P \text { increase with decrease of Louver } \\
\text { pitch and axis ratio. } \\
\text { 3. } \Delta P \text { increases significantly with increase in } \theta .\end{array}$ \\
\hline 7 & $\begin{array}{l}\text { Kim and } \\
\text { Bullard } \\
(2002)\end{array}$ & $\begin{array}{l}\text { Experimental/ } \\
\text { Flat }\end{array}$ & $\begin{array}{l}\text { 1. } 45 \text { multilouver fin geometries were studied. } \\
\text { 2. Correlations for } j \text { and } f \text { factors were developed } \\
\text { with errors of } \pm 14.5 \% \text { and } \pm 7 \% \text {, respectively. }\end{array}$ \\
\hline 8 & $\begin{array}{l}\text { Hsieh and } \\
\text { Jang (2006, } \\
\text { 2012) }\end{array}$ & $\begin{array}{l}\text { Numerical/ } \\
\text { No tube }\end{array}$ & $\begin{array}{l}\text { 1. Louver fin with variable } \theta \text { was investigated. } \\
\text { 2. Up to } 25.5 \% \text { area reduction can be achieved in } \\
\text { louver fin with variable } \theta \text { in comparison with plain fin. } \\
\text { 3. Optimization of louver fin-and-tube heat } \\
\text { exchangers was performed using Taguchi method. }\end{array}$ \\
\hline
\end{tabular}

Volume 27, Issue 4, 2020 
TABLE 1: (continued)

\begin{tabular}{|c|c|c|c|}
\hline No. & Research & $\begin{array}{c}\text { Research type/ } \\
\text { Tube type }\end{array}$ & Major conclusions \\
\hline 9 & \begin{tabular}{|} 
Malapure \\
et al. (2007)
\end{tabular} & Numerical/Flat & $\begin{array}{l}\text { 1. At lower Re, flow is along fin, while at higher Re, } \\
\text { flow is directed along louvers. } \\
\text { 2. St and } f \text { decrease with } F_{p} \text { increase. }\end{array}$ \\
\hline 10 & $\begin{array}{l}\text { Li and } \\
\text { Wang } \\
(2010)\end{array}$ & $\begin{array}{c}\text { Experimental/ } \\
\text { Flat }\end{array}$ & $\begin{array}{l}\text { 1. 4-region and 6-region louver fins have } \\
\text { improvements in comparison with traditional fin. } \\
\text { 2. Developed correlations for } j \text { and } f \text { can predict } \\
\text { 85\% of experimental results within } \pm 10 \% \text { and } \pm 20 \% \text {, } \\
\text { respectively. }\end{array}$ \\
\hline 11 & $\begin{array}{l}\text { T'Joen et al. } \\
\text { (2011a) }\end{array}$ & $\begin{array}{l}\text { Numerical and } \\
\text { experimental/ } \\
\text { No tube }\end{array}$ & $\begin{array}{l}\text { 1. Inclined louver fin, which is a compound design } \\
\text { of slit and louver fins, was investigated. } \\
\text { 2. At low Re, flow is changed to unsteady because of } \\
\text { recirculation zones that exist on the inclined regions in } \\
\text { the fin array. } \\
\text { 3. Inclined louver fin can perform better than louver } \\
\text { and slit fins at low Re. }\end{array}$ \\
\hline 12 & $\begin{array}{l}\text { T'Joen et al. } \\
\text { (2011b) }\end{array}$ & $\begin{array}{l}\text { Numerical and } \\
\text { experimental/ } \\
\text { No tube }\end{array}$ & $\begin{array}{l}\text { 1. A hybrid design of slit fin and standard louver fin } \\
\text { was presented. } \\
\text { 2. Flow visualization was performed in the water } \\
\text { tunnel. }\end{array}$ \\
\hline 13 & $\begin{array}{l}\text { Vaisi et al. } \\
\text { (2011) }\end{array}$ & $\begin{array}{l}\text { Experimental/ } \\
\text { Flat }\end{array}$ & $\begin{array}{l}\text { In louver fins, symmetrical arrangement results in } \\
9.3 \% \text { rise in } h \text { and } 18.2 \% \text { reduction in } \Delta P \text { in } \\
\text { comparison with asymmetrical arrangement. }\end{array}$ \\
\hline 14 & $\begin{array}{l}\text { Dai et al. } \\
\text { (2012) }\end{array}$ & Analytical/Flat & $\begin{array}{l}\text { 1. Comparisons between heat exchangers made from } \\
\text { metal foam with typical louver fin heat exchanger } \\
\text { were performed. } \\
\text { 2. Metal foam heat exchanger is smaller and lighter } \\
\text { than louver fin heat exchanger in the same fan power, } \\
\text { but it is more expensive. }\end{array}$ \\
\hline 15 & $\begin{array}{l}\text { Han et al. } \\
\text { (2013) }\end{array}$ & $\begin{array}{l}\text { Numerical/Oval } \\
\text { and circular }\end{array}$ & $\begin{array}{l}\text { 1. Wavy and louver fin-and-tube heat exchangers } \\
\text { were studied. } \\
\text { 2. Using oval tube in heat exchangers decreases flow } \\
\text { resistance and augment heat transfer capacity, which } \\
\text { results in rise in fin efficiency. }\end{array}$ \\
\hline 16 & $\begin{array}{c}\text { Čarija et al. } \\
(2014)\end{array}$ & Numerical/Flat & $\begin{array}{l}\text { 1. CFD simulations were done in } 70<\mathrm{Re}<350 \text {. } \\
\text { 2. Flat fin and louver fin were compared. } \\
\text { 3. Using louver fin, up to } 58 \% \text { rise of heat transfer } \\
\text { performance is found in } \mathrm{Re}=350 \text { in comparison to } \\
\text { flat fin. }\end{array}$ \\
\hline 17 & $\begin{array}{c}\text { Dogan et al. } \\
\text { (2015) }\end{array}$ & $\begin{array}{l}\text { Experimental/ } \\
\text { Flat }\end{array}$ & $\begin{array}{c}\text { 1. } \begin{array}{c}\text { Double-row louver fin was compared with } \\
\text { triple-row louver fin. }\end{array} \\
\text { 2. Considering NTU and effectiveness, double-row } \\
\text { louver fin is more effective. }\end{array}$ \\
\hline
\end{tabular}


TABLE 1: (continued)

\begin{tabular}{|c|c|c|c|}
\hline No. & Research & $\begin{array}{l}\text { Research type/ } \\
\text { Tube type }\end{array}$ & Major conclusions \\
\hline 18 & $\begin{array}{l}\text { Jang and } \\
\text { Chen } \\
(2015)\end{array}$ & $\begin{array}{l}\text { Numerical and } \\
\text { experimental/ } \\
\text { No tube }\end{array}$ & $\begin{array}{l}\text { 1. Louver fin with variable } \theta \text { was optimized. } \\
\text { 2. At } 133<\operatorname{Re}<1199 \text {, optimum design proposes } \\
48.5 \%-55.2 \% \text { reduction in area. }\end{array}$ \\
\hline 19 & $\begin{array}{l}\text { Karthik } \\
\text { et al. } \\
(2015 b)\end{array}$ & $\begin{array}{c}\text { Numerical and } \\
\text { experimental/ } \\
\text { Elliptical }\end{array}$ & $\begin{array}{l}\text { For increasing the overall } h \text {, influence of rise of air } \\
\text { velocity is greater than rise of water mass flow rate. }\end{array}$ \\
\hline 20 & $\begin{array}{l}\text { Karthik } \\
\text { et al. } \\
(2015 \mathrm{a})\end{array}$ & $\begin{array}{l}\text { Numerical and } \\
\text { experimental/ } \\
\text { Flat }\end{array}$ & $\begin{array}{l}\text { 1. Decrease in } F_{p} \text { leads to the higher } \Delta P \text { at a given } \\
\text { frontal air velocity, but } h \text { increases in proportion with } \\
\qquad F_{p} \text {. } \\
\text { 2. The effect of increase in both } P_{t} \text { and } P_{l} \text { results in } \\
\text { higher } \Delta P \text {, while the effect of these parameters on } h \\
\text { is very minimal. }\end{array}$ \\
\hline 21 & $\begin{array}{l}\text { Wang et al. } \\
(2015)\end{array}$ & $\begin{array}{l}\text { Experimental/ } \\
\text { Circular }\end{array}$ & $\begin{array}{l}\text { 1. } 18 \text { samples of fin-and-tube heat exchangers with } \\
\text { plain fin, louver fin, and semi-dimple vortex generator } \\
\text { were tested. } \\
\text { 2. For plain fin in } N>1 \text {, louver fin, and } \\
\text { semi-dimple vortex generator, effect of } N \text { on } h \text { is } \\
\text { insignificant. }\end{array}$ \\
\hline 22 & $\begin{array}{c}\text { Srinivasu } \\
\text { et al. (2016) }\end{array}$ & Numerical/Flat & $\begin{array}{l}\text { 1. Using water/ethyl glycol and } \mathrm{Al}_{2} \mathrm{O}_{3} \text { nano fluid in } \\
\text { a radiator with louver fin was investigated. } \\
\text { 2. Rise of volumetric concentration of nanoparticles } \\
\text { enhances the efficiency of heat transfer. }\end{array}$ \\
\hline 23 & $\begin{array}{l}\text { Erbay et al. } \\
(2017)\end{array}$ & Numerical/Flat & $\begin{array}{l}\text { 1. } 2 \text { D numerical simulations were performed. } \\
\text { 2. } \quad f \text { decreases with increasing } F_{p} \text { and Re. } \\
\quad j \text { increases when Re decreases. } \\
\text { 3. Using volume goodness factor, maximum } \\
\text { performance is achieved at } \theta=20^{\circ} \text { and } F_{p}=1.5 \mathrm{~mm} \text {. }\end{array}$ \\
\hline 24 & $\begin{array}{l}\text { Javaherdeh } \\
\text { et al. (2017) }\end{array}$ & Numerical/Flat & $\begin{array}{l}\text { 1. Increasing } \theta \text { leads to increase in } h \text { and } \Delta P \text { and } \\
\text { suitable } \theta \text { varies from } 24^{\circ} \text { to } 32^{\circ} \text {. } \\
\text { 2. Better performance can be obtained by smaller } \\
\text { louver pitch and higher louver number. } \\
\text { 3. Optimization of the inlet and exit nonlouver } \\
\text { regions were carried out. }\end{array}$ \\
\hline 25 & $\begin{array}{c}\text { Hrnjak et al. } \\
(2017)\end{array}$ & $\begin{array}{l}\text { Experimental/ } \\
\text { No tube }\end{array}$ & $\begin{array}{l}\text { 1. Effects of } \theta\left(15^{\circ}, 27^{\circ} \text {, and } 39^{\circ}\right) \text { for three } F_{p}(2.12, \\
\text { 1.41, and } 1.69 \mathrm{~mm}) \text { on } \Delta P \text { and overall } h \text { of serpentine } \\
\text { louver fin under periodic frosting were studied. } \\
\text { 2. Performance of heat exchangers under frosting } \\
\text { condition shall be in accordance with several-cycle } \\
\text { experiments. } \\
\text { 3. Under frosting condition, a larger louver pitch } \\
\text { outperforms smaller ones. }\end{array}$ \\
\hline
\end{tabular}

Volume 27, Issue 4, 2020 
TABLE 1: (continued)

\begin{tabular}{|c|c|c|c|}
\hline No. & Research & $\begin{array}{c}\text { Research type/ } \\
\text { Tube type }\end{array}$ & Major conclusions \\
\hline 26 & $\begin{array}{l}\text { Okbaz et al. } \\
\text { (2018) }\end{array}$ & $\begin{array}{l}\text { Experimental/ } \\
\text { Circular }\end{array}$ & $\begin{array}{l}\text { 1. Flow visualization using PIV (particle image } \\
\text { velocimetry) method was performed. } \\
\text { 2. Louver fin was compared with wavy fin with the } \\
\text { same size and specifications. } \\
\text { 3. Thermal and hydraulic performances of louver fin } \\
\text { are higher than wavy fin. }\end{array}$ \\
\hline 27 & $\begin{array}{l}\text { Sadeghian- } \\
\text { jahromi } \\
\text { et al. } \\
\text { (2018a) }\end{array}$ & $\begin{array}{l}\text { Numerical/ } \\
\text { Circular }\end{array}$ & $\begin{array}{l}\text { 1. Proposed correlations regarding } j \text { and } f \text { factors } \\
\text { can predict } 100 \% \text { and } 86 \% \text { of data obtained by } \\
\text { numerical simulation in } \pm 15 \% \text {, respectively. } \\
\text { 2. Optimum } \theta \text { using genetic algorithm was obtained } \\
\text { by utilizing developed correlations. }\end{array}$ \\
\hline 28 & $\begin{array}{l}\text { Asadi et al. } \\
\text { (2018) }\end{array}$ & $\begin{array}{l}\text { Numerical/ } \\
\text { No tube }\end{array}$ & $\begin{array}{c}\text { The constructal law was used to optimize the channel } \\
\text { geometry with louver fins by changing louver pitch } \\
\text { ratio, louver angle ratio, and inlet to outer louver } \\
\text { length ratio. }\end{array}$ \\
\hline 29 & $\begin{array}{l}\text { Qian et al. } \\
\text { (2018) }\end{array}$ & $\begin{array}{l}\text { Numerical/ } \\
\text { Circular }\end{array}$ & $\begin{array}{l}\text { 1. Linear-up velocity profile is compared with } \\
\text { linear-down profile in louver fins. } \\
\text { 2. Linear-up velocity profile has } 13 \%-32 \% \text { lower Nu } \\
\text { and 61\%-66\% lower } \Delta P \text { compared to uniform } \\
\text { velocity profile. } \\
\text { 3. Linear-down velocity profile has } 26 \%-34 \% \\
\text { higher Nu and } 80 \%-89 \% \text { higher } \Delta P \text { compared to } \\
\text { uniform velocity profile. }\end{array}$ \\
\hline
\end{tabular}

Upon Table 1, the following summary is concluded:

1. Most of the studies have been carried out on louver fin-and-flat tube heat exchangers (Achaichia and Cowell, 1988; Atkinsona et al., 1998; Čarija et al., 2014; Cowell et al., 1995; Dai et al., 2012; Dogan et al., 2015; Erbay et al., 2017; Javaherdeh et al., 2017; Karthik et al., 2015a; Kim and Bullard, 2002; Li and Wang, 2010; Malapure et al., 2007; Srinivasu et al., 2016; Vaisi et al., 2011), while louver fin-and-circular tube heat exchangers have been taken into consideration by comparatively few researchers.

2. Complete elaborations regarding parametric study (especially those parameters which depend on geometry) requires numerous and tedious models for simulations, which is time-consuming. Therefore, in spite of this fact that many phenomena can be discovered in parametric studies, researchers are less interested in parametric study. So, sufficient parametric studies and optimizations have not been performed on louver parameters, especially on louver angles (Hsieh and Jang, 2012; Jang and Chen, 2015; Javaherdeh et al., 2017). Furthermore, the ranges of louver angle considered in different studies are limited, while louver angles ranging from $0^{\circ}$ to near $90^{\circ}$ have not been investigated in different studies. 
3. Although experimental studies have been carried out on louver fins, observations and results obtained by performing numerical simulations cannot be achieved by experimental analysis because the dimensions of louvers are very small and exact louver angles are difficult to measure correctly, thereby some uncertain errors in the experimental measurements may prevail. Also, for such compact geometries, using the experimental instruments such as pressure or temperature measurement tools to measure the local thermalhydraulic characteristics might offer another interference upon the flow pattern. Thus, it is only probable to measure bulk parameters such as inlet and outlet pressure or temperature differences and nothing about the flow pattern details, recirculation zones, and so on are in hand. Conversely, modeling of louver fins with exact dimensions and performing flow visualization between louvers are easily possible in numerical analysis.

In this study, three-dimensional simulations are performed on both flat and louver fin-andtube heat exchangers with circular tubes considering turbulent flow. The effects of different geometrical parameters on heat transfer (Colburn factor) and flow friction (friction factor) characteristics of louver fin-and-tube heat exchangers in wide ranges of louver angles from $0^{\circ}$ (flat fin) to $80^{\circ}$ are analyzed numerically. Detailed study of flow visualization between tubes and louver fins is executed. Also, optimization of louver angle is done by full factorial method. The results can be taken into consideration in design and optimization of louver fins, which are the most efficient fins and are widely used in applications and industries. Because louver angle is the most effective parameter of louver fins, the maximum ranges from $0^{\circ}$ to $80^{\circ}$ have been considered for louver angle in order to investigate its behavior thoroughly, which has been never done before.

\section{MODEL DESCRIPTION}

Figure 1 shows physical model and geometrical properties of a simulated louver fin-and-tube heat exchanger. The computational domain is also illustrated in Fig. 2. Basic values for simulated geometries in the validating cases (flat fin and louver fin) and parametric studies are specified in Table 2.

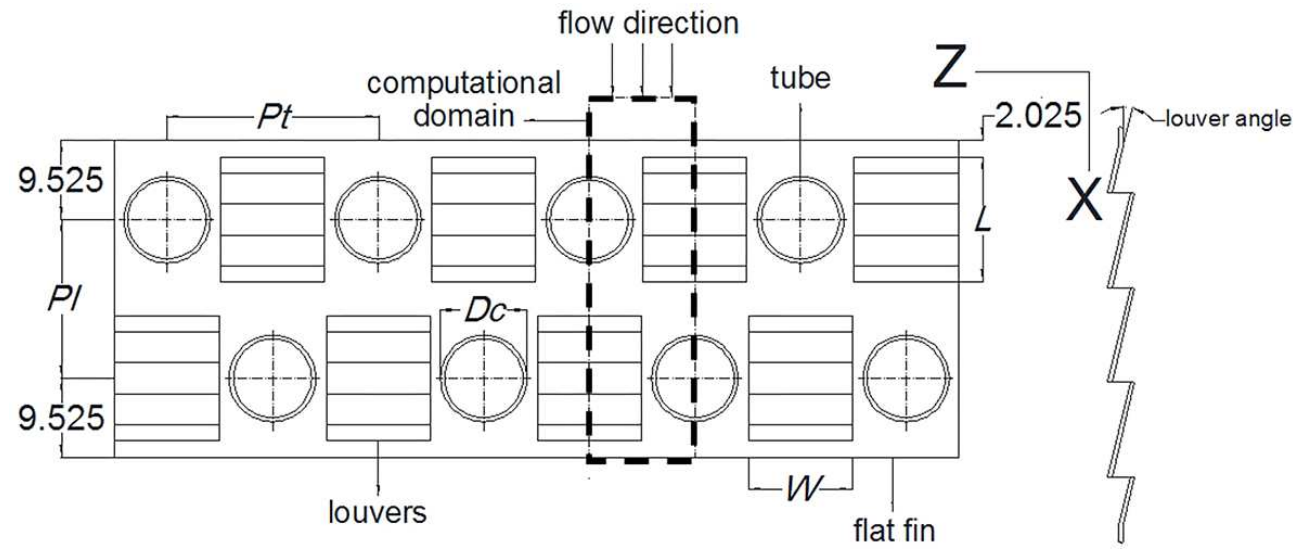

FIG. 1: Physical model of simulated louver fin (all dimensions are in $\mathrm{mm}$ )

Volume 27, Issue 4, 2020 


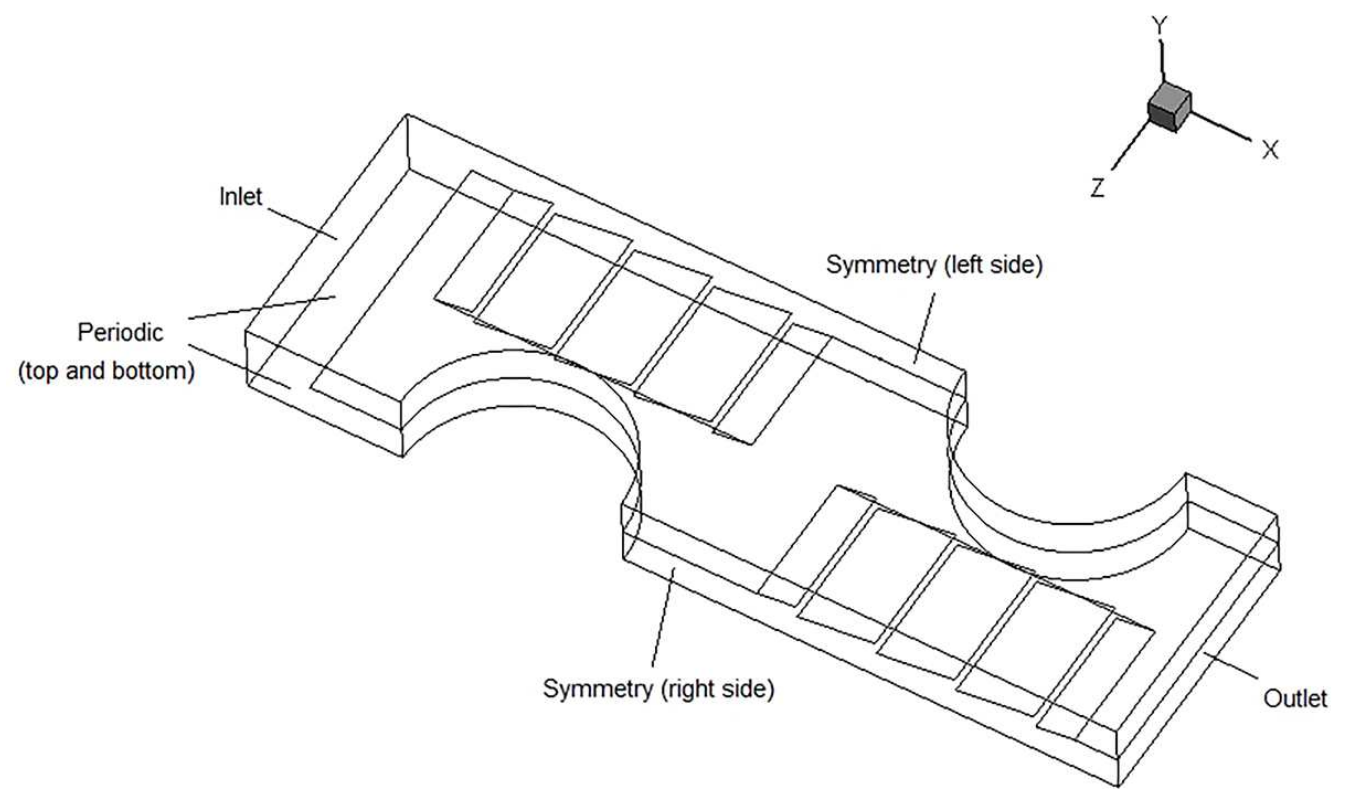

FIG. 2: Computational domain of simulated louver fins

TABLE 2: Basic geometrical parameters for validation and parametric studies

\begin{tabular}{|c|c|c|c|}
\hline Parameters & Parametric study & Validation of louver fin & Validation of flat fin \\
\hline$D_{c}(\mathrm{~mm})$ & 10.42 & 10.42 & 10.23 \\
\hline$N$ & 2 & 2 & 2 \\
\hline$t(\mathrm{~mm})$ & 0.115 & 0.115 & 0.13 \\
\hline$L(\mathrm{~mm})$ & 15 & 15 & - \\
\hline$N_{l}$ & 4 & 4 & - \\
\hline$W(\mathrm{~mm})$ & 12.7 & 12.5 & - \\
\hline$F_{p}(\mathrm{~mm})$ & 3.75 & 2.06 & 2.24 \\
\hline$P_{l}(\mathrm{~mm})$ & 19.05 & 19.05 & 22 \\
\hline$P_{t}(\mathrm{~mm})$ & 25.4 & 25.4 & 25.4 \\
\hline$\theta\left({ }^{\circ}\right)$ & $0-80$ & 13.5 & - \\
\hline
\end{tabular}

\subsection{Governing Equations}

Governing equations for numerical simulations including continuity, momentum (RANS), and energy can be obtained on the basis of the following assumptions:

- The flow is steady, three-dimensional, incompressible, and turbulent.

- Air is working fluid, while its properties are assumed to be constant.

- Thermal radiation and natural convection can be ignored.

Therefore, the governing equations can be expressed as follows: 
Continuity equation (Sadeghianjahromi et al., 2018a):

$$
\frac{\partial \bar{u}_{i}}{\partial x_{i}}=0
$$

Momentum equation (Sadeghianjahromi et al., 2018a):

$$
\frac{\partial}{\partial x_{j}} \rho\left(\overline{u_{i} u_{j}}\right)=-\frac{\partial \bar{P}}{\partial x_{i}}+\frac{\partial}{\partial x_{j}}\left[\mu_{e f f}\left(\frac{\partial \bar{u}_{i}}{\partial x_{j}}+\frac{\partial \bar{u}_{j}}{\partial x_{i}}\right)-\rho\left(\overline{u_{i}^{\prime} u_{j}^{\prime}}\right)\right]
$$

Energy equation (Sadeghianjahromi et al., 2018a):

$$
\frac{\partial}{\partial x_{j}} \rho C\left(\overline{u_{j} T}\right)=\bar{u}_{j} \frac{\partial \bar{P}}{\partial x_{j}}+\bar{u}_{j}^{\prime} \frac{\partial \bar{P}^{\prime}}{\partial x_{j}}+\frac{\partial}{\partial x_{j}}\left[k_{f} \frac{\partial \bar{T}}{\partial x_{j}}-\rho C \overline{u_{j}^{\prime} T^{\prime}}\right]
$$

where $\rho, P, u, C, T$, and $k_{f}$ are density, pressure, velocity, heat capacity, temperature, and fluid thermal conductivity, respectively. Mean values are denoted by bar signs, and fluctuations relative to mean values are shown by prime signs. $\mu_{e f f}$ is the effective turbulent viscosity and is defined as follows:

$$
\mu_{e f f}=\mu+\mu_{t}
$$

To simulate the turbulent viscosity, $\mu_{t}$, the renormalization group (RNG) $k$ - $\varepsilon$ model was used as the turbulence model. It consists of two extra equations to calculate kinetic energy $(k)$ and dissipation rate $(\varepsilon)$ as follows:

$$
\begin{gathered}
\frac{\partial}{\partial x_{i}}\left(\rho k \bar{u}_{i}\right)=\frac{\partial}{\partial x_{j}}\left(\alpha_{k} \mu_{e f f} \frac{\partial k}{\partial x_{j}}\right)+G_{k}-\rho \varepsilon \\
\frac{\partial}{\partial x_{i}}\left(\rho \varepsilon \bar{u}_{i}\right)=\frac{\partial}{\partial x_{j}}\left(\alpha_{k} \mu_{e f f} \frac{\partial \varepsilon}{\partial x_{j}}\right)+C_{1 \varepsilon} \frac{\varepsilon}{k}\left(G_{k}\right)-C_{2 \varepsilon}^{*} \rho \frac{\varepsilon^{2}}{k}
\end{gathered}
$$

One can find more details about RNG theory in Orszag et al. (1993). $Y^{+}<5$ is considered in numerical simulations since enhanced wall function is utilized for wall function.

\subsection{Boundary Conditions and Numerical Method}

Boundary conditions for numerical simulations are specified in the computational domain (Fig. 2). Air inlet velocity to the computational domain ( $x$ direction) is uniform and in the range of $1-6.5 \mathrm{~m} / \mathrm{s}$, while its components in other directions ( $y$ and $z$ ) are zero. Also, air inlet temperature $\left(T_{\mathrm{in}}\right)$ is considered constant at $303.15 \mathrm{~K}$. Atmospheric pressure is assigned for pressure at air outlet. Normal gradients are supposed to be zero for side boundaries (symmetric planes). Wall temperatures are constant, which are equal to $333.15 \mathrm{~K}$ and $338.15 \mathrm{~K}$ for flat fin and louver fin validations, respectively. Parametric studies are performed with constant wall temperature of 338.15 K and no-slip condition for solid surfaces. Top and bottom boundaries are assumed to be periodic.

Governing equations are solved using traditional computational fluid dynamics (CFD) software, Ansys Fluent software (version 2019 R3). A SIMPLE algorithm is used to couple pressure and momentum equations. The discretized equations are solved by software until convergence occurs for which residuals are set to be less than $10^{-6}$.

A grid study is done for both flat fin and louver fin in maximum inlet velocity by different number of grid cells, as illustrated in Fig. 3. Based on the grid study, grid cell sizes are selected less than $0.2 \mathrm{~mm}$. It should be noted that for keeping $Y^{+}<5$, some cells are adopted near solid wall surfaces.

Volume 27, Issue 4, 2020 


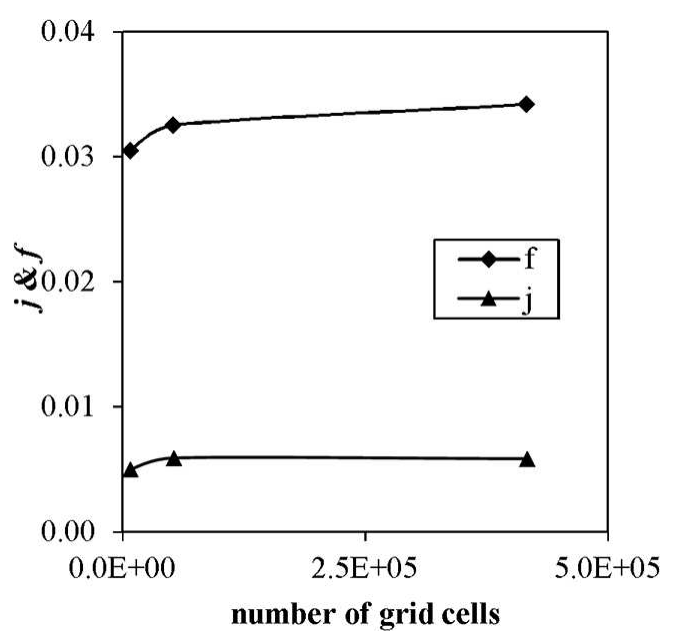

(a)

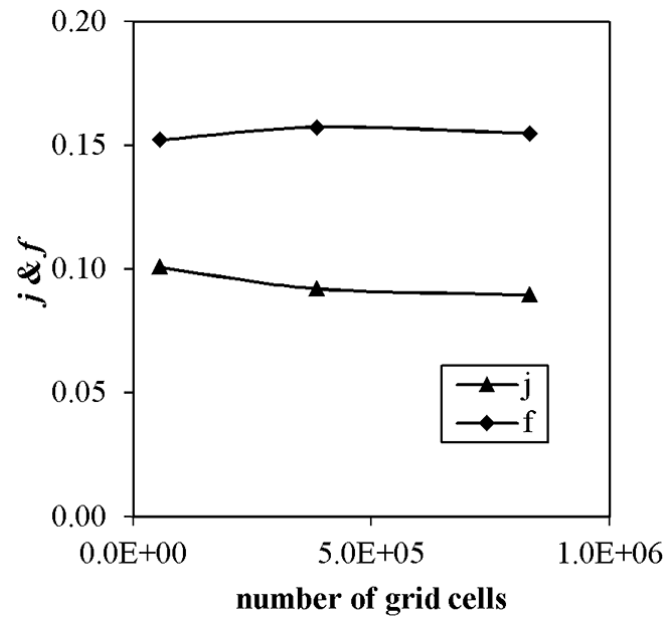

(b)

FIG. 3: Grid study for modeling of (a) flat fin and (b) louver fin

\subsection{Parameter Definitions}

In order to consider the effect of properties of fluids in Stanton number, this nondimensional parameter is modified to a new nondimensional parameter, Colburn factor $(j)$, which is almost independent of fluid properties for $0.5 \leq \operatorname{Pr} \leq 10$. Colburn factor is usually used for illustration of heat transfer performance (Shah and Sekulic, 2003). Colburn $j$ factor can be described as follows (Wang et al., 1996):

$$
j=\frac{\mathrm{Nu}}{\operatorname{Re}_{D_{c}} \cdot \operatorname{Pr}^{1 / 3}}
$$

where Prandtl number is denoted by Pr. Reynolds number, $\operatorname{Re}_{D_{c}}$, which is defined based on tube collar outside diameter $\left(D_{c}\right)$, can be determined from the following correlation (Wang et al., 1996):

$$
\operatorname{Re}_{D_{c}}=\frac{\rho V_{\max } D_{c}}{\mu}
$$

where $V_{\max }, \rho$, and $\mu$ are maximum velocity, density, and dynamic viscosity of air, respectively.

Nusselt number $(\mathrm{Nu})$ is defined based on tube collar outside diameter $\left(D_{c}\right)$ as $\mathrm{Nu}=h D_{c} / k_{f}$ where $k_{f}$ and $h$ are fluid thermal conductivity and heat transfer coefficient, respectively. Since all solid surfaces have constant temperatures, surface efficiency $\left(\eta_{o}\right)$ is related to fin efficiency

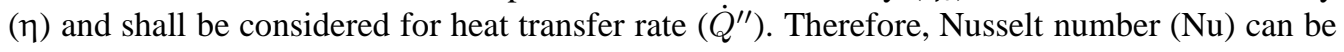
attained from numerical simulations in accordance with the following correlation:

$$
\mathrm{Nu}=\frac{\eta_{o} \dot{Q}^{\prime \prime} D_{c}}{\Delta T_{l m} \cdot k_{f}}
$$

where $\Delta T_{l m}$ is logarithmic mean temperature difference, which can be obtained from the following formula (Nemati and Moghimi, 2014; Shah and Sekulic, 2003):

$$
\Delta T_{l m}=\frac{T_{\text {out }}-T_{\text {in }}}{\ln \left[\left(T_{s}-T_{\text {in }}\right) /\left(T_{s}-T_{\text {out }}\right)\right]}
$$


where constant wall surface temperature is denoted by $T_{s}$ and $T_{\text {out }}$ and $T_{\text {in }}$ represent air outlet and inlet temperatures, respectively. Surface efficiency $\left(\eta_{o}\right)$ is described in accordance with the following correlation (Wang et al., 1996):

$$
\eta_{o}=1-\frac{A_{f}}{A_{o}}(1-\eta)
$$

where $A_{o}$ represents total surface area and $A_{f}$ is fin surface area. Fin efficiency ( $\left.\eta\right)$ is determined by the following formula (Nemati and Samivand, 2014):

$$
\eta=\left[\frac{\tanh \left(m\left(r_{f}-r\right) \psi\right)}{m\left(r_{f}-r\right) \psi}\right]^{\psi}
$$

where $r$ and $r_{f}$ are tube radius and equivalent circular fin radius, respectively. $m$ is a thermogeometry parameter and can be calculated as follows (Nemati and Samivand, 2014):

$$
m=\sqrt{\frac{2 h}{k_{f i n} t}}
$$

where $h$ is fluid heat transfer coefficient and $k_{\text {fin }}$ and $t$ are fin thermal conductivity and thickness, respectively. $\psi$ is fin efficiency parameter, which can be obtained from the following equation (Nemati and Samivand, 2014):

$$
\psi=1+0.17912 \ln \left(r_{f} / r\right)
$$

where $r$ and $r_{f}$ are tube radius and equivalent circular fin radius, respectively and $r_{f} / r$ can be determined from the following equation (Wang et al., 1996):

$$
r_{f} / r=1.27\left(P_{t} / 2 r\right)\left[\left(0.5 \sqrt{P_{l}^{2}+\left(P_{t} / 2\right)^{2}}\right) /\left(P_{t} / 2\right)-0.3\right]^{1 / 2}
$$

where $P_{t}$ and $P_{l}$ are transversal and longitudinal tube pitches, respectively.

Friction factor $(f)$ can be calculated as follows based on Kays and London's definition (Kays and London, 1984):

$$
f=\frac{A_{c}}{A_{o}} \frac{\rho_{m}}{\rho_{\text {in }}}\left[\frac{2 \rho_{\text {in }} \Delta P}{G^{2}}-\left(K_{c}+1-\sigma^{2}\right)-2\left(\frac{\rho_{\text {in }}}{\rho_{\text {out }}}-1\right)+\left(1-\sigma^{2}-K_{e}\right) \frac{\rho_{\text {in }}}{\rho_{\text {out }}}\right]
$$

where $\sigma$ is minimum to frontal flow area ratio. $A_{o}$ represents total heat transfer area, and $A_{c}$ is flow cross-sectional area. $K_{c}$ and $K_{e}$, which are assumed zero in calculations, are entrance and exit loss coefficients, respectively. $\rho_{\text {in }}, \rho_{\text {out }}$, and $\rho_{m}$ are air densities at inlet, outlet, and mean value, respectively. $\Delta P$ is pressure drop, while air mass flux is denoted by $G$.

\subsection{Model Validation}

Experimental data obtained by Wang and colleagues for fin-and-tube heat exchangers having plain fin (Wang et al., 1996) and louver fin (Wang et al., 1998a) with circular tubes is used for validation of the numerical simulations. Geometrical parameters are specified in Table 2. Comparisons of calculated Colburn $(j)$ and friction $(f)$ factors from numerical simulations of flat and

Volume 27, Issue 4, 2020 
louver fin-and-tube heat exchangers with experimental data are shown in Figs. 4 and 5, respectively. The mean deviations for $j$ and $f$ factors for both flat and louver fins in comparison with the experimental results are specified in Table 3. Also, the reported experimental uncertainties for $j$ and $f$ factors for plain fin (Wang et al., 1996) and louver fin (Wang et al., 1998a) are listed in Table 3. The results show the applicability of the present numerical simulations.

\section{PARAMETRIC STUDY}

Parametric studies for investigation of effects of louver angle $(\theta)$, fin pitch $\left(F_{p}\right)$, transversal tube pitch $\left(P_{t}\right)$, and longitudinal tube pitch $\left(P_{l}\right)$ on Colburn factor $(j)$ and friction factor $(f)$ of louver fin-and-tube heat exchangers were performed. Basic geometrical parameters were the same as those in Table 2.

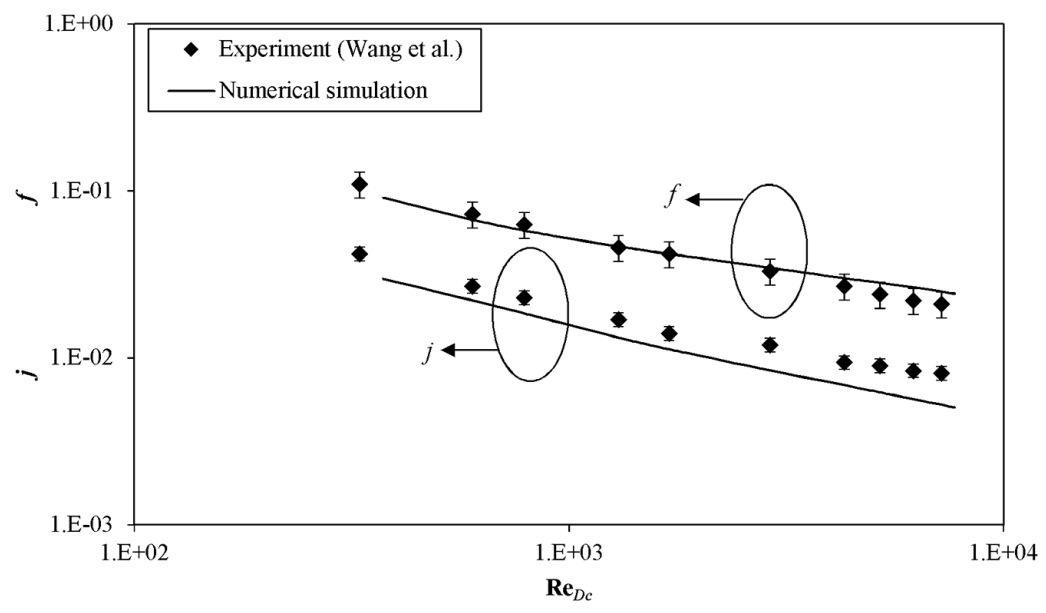

FIG. 4: Comparison of numerical results with experimental data from Wang et al. (1996) for flat fin

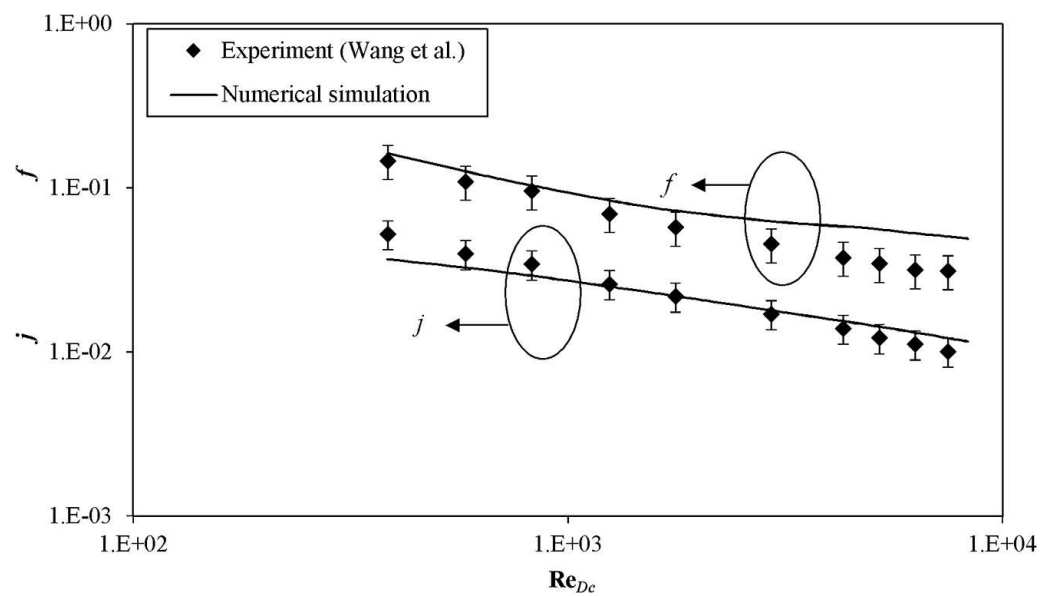

FIG. 5: Comparison of numerical results with experimental data from Wang et al. (1998a) for louver fin 
TABLE 3: Reported experimental uncertainties and validation mean deviations

\begin{tabular}{|l|c|c|c|c|}
\hline \multirow{2}{*}{ Parameters } & \multicolumn{2}{|c|}{ Reported experimental uncertainties } & \multicolumn{2}{c|}{ Validation mean deviations } \\
\cline { 2 - 5 } & $\begin{array}{c}\text { Flat fin (Wang } \\
\text { et al., 1996) }\end{array}$ & $\begin{array}{c}\text { Louver fin (Wang } \\
\text { et al., 1998a) }\end{array}$ & Flat fin & Louver fin \\
\hline Colburn factor & $3.9 \%-9.4 \%$ & $5.2 \%-20.2 \%$ & $28 \%$ & $13 \%$ \\
\hline Friction factor & $1.3 \%-17.7 \%$ & $7.3 \%-23.4 \%$ & $10 \%$ & $30 \%$ \\
\hline
\end{tabular}

\subsection{Effect of Louver Angle}

In order to examine the effect of louver angle on the heat transfer and friction factor of louver finand-tube heat exchangers, louver angle was raised from $0^{\circ}$ (flat fin) to $80^{\circ}$ and other parameters were fixed as tabulated in Table 2. $u_{\text {in }}$ is changed from 1 to $6.5 \mathrm{~m} / \mathrm{s}$ with corresponding Reynolds number ranging from 1248 to 8111 . Figure 6 shows $j$ and $f$ factors vs. louver angles in different Reynolds numbers. The tendency of $j$ factor vs. louver angle is characterized into three stages. Initially, the $j$ factor increases with the rise of louver angle up to a certain threshold value (around $20^{\circ}$ ), followed by a slight level-off or decline with a louver angle toward $45^{\circ}$, and finally a slight uplift is seen when surpassing the $45^{\circ}$ louver angle. In the first stage, it is clear that $j$ factor increases linearly (approximately with slope of $3 \%$ for $\mathrm{Re}=1248$ ) with variation of louver angle $(\theta)$ from $0^{\circ}$ to $20^{\circ}$, followed by a detectable decline when the louver angle is raised from $20^{\circ}$ to $45^{\circ}$. Finally, it increases linearly again (approximately with slope of $1 \%$ for $\operatorname{Re}=1248$ ) from louver angle $45^{\circ}$ to $80^{\circ}$. This phenomenon persists for all Reynolds numbers (from 1248 to 8111). It is quite clear that the Colburn factor of louver fin, regardless of louver angle, is much higher than the Colburn factor with plain fin (louver fin with $\theta=0^{\circ}$ ). It is illustrated that the slopes of variations of Colburn factor in the higher Reynolds number regime are less pronounced than the one in lower Reynolds numbers. Also, it is quite clear that with the rise in louver angle from $\theta=0^{\circ}$ to $\theta=60^{\circ}$, friction factor increases rather slightly (with a very small slope of $1 \%$ ) for all Reynolds numbers. However, once the louver angle surpasses $60^{\circ}$, the louvers act as obstacles that block the airflow considerably, and thereby causing a surging rise of friction factor. Moreover, it is indicated that Colburn $(j)$ factor and friction $(f)$ factor decrease with increase

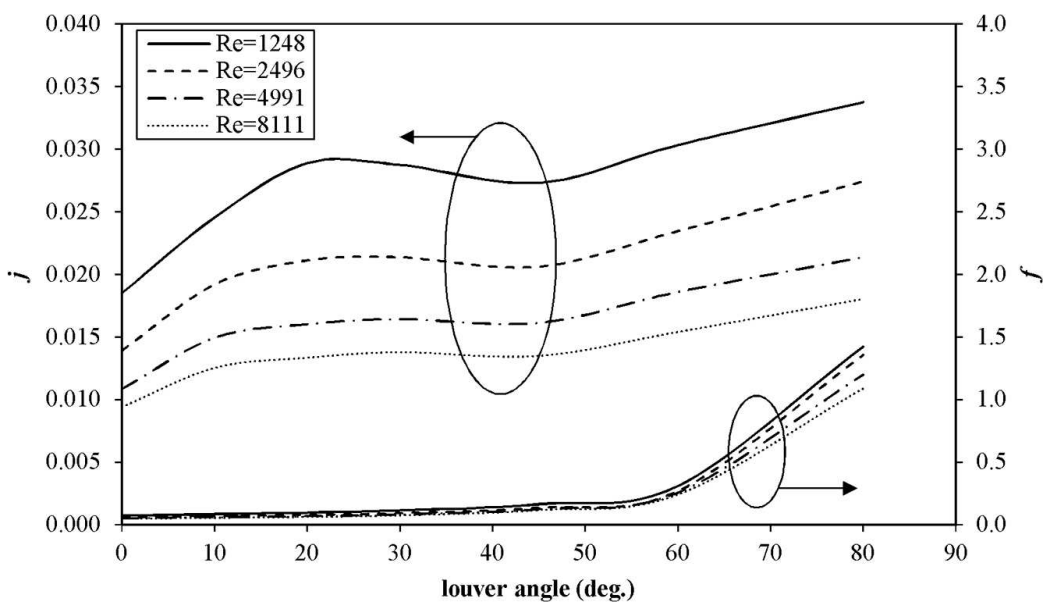

FIG. 6: Effect of louver angle on $j$ and $f$ factors in different Reynolds numbers

Volume 27, Issue 4, 2020 
in Reynolds numbers in the same louver angle. Both heat transfer $\left(\dot{Q}^{\prime \prime}\right)$ and pressure loss $(\Delta P)$ increase with increase in Reynolds number, but the amount of increase in Reynolds number is much higher than increase in heat transfer $\left(\dot{Q}^{\prime \prime}\right)$ and pressure loss $(\Delta P)$. Consequently, $j$ and $f$ factors decrease.

For further elaboration of the influence of louver angle on Colburn factor, air flow temperature contours with velocity vectors and 3D pathlines on the left symmetry plane of Fig. 2 for four fin rows are shown in Figs. 7 and 8 subject to different louver angles ranging from $\theta=0^{\circ}$

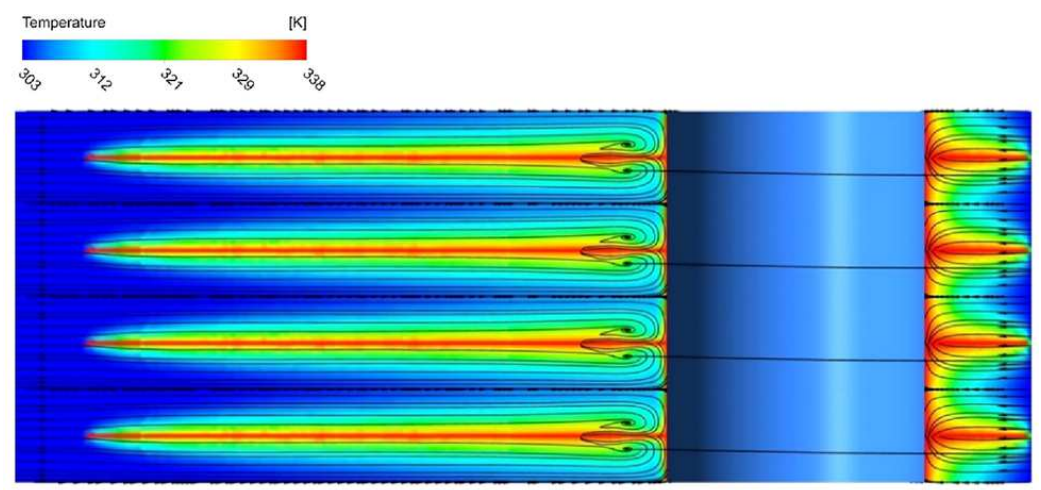

a) Louver angle $0^{\circ}$ (flat fin)

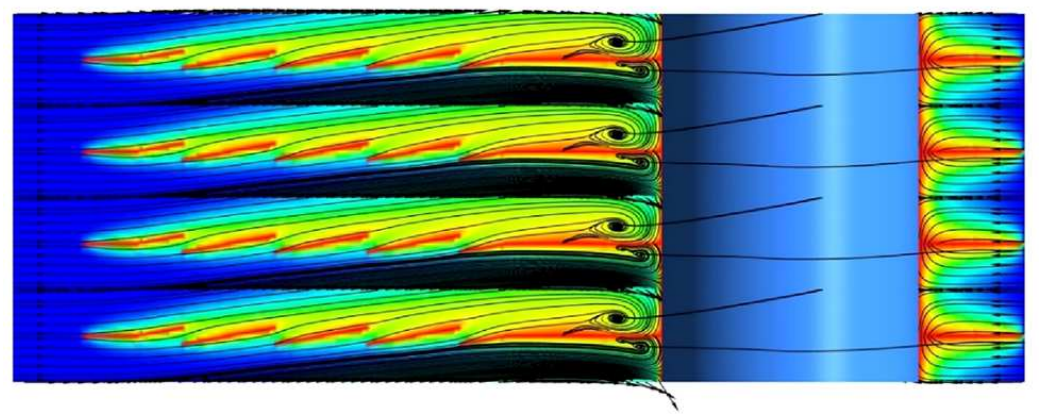

b) Louver angle $10^{\circ}$

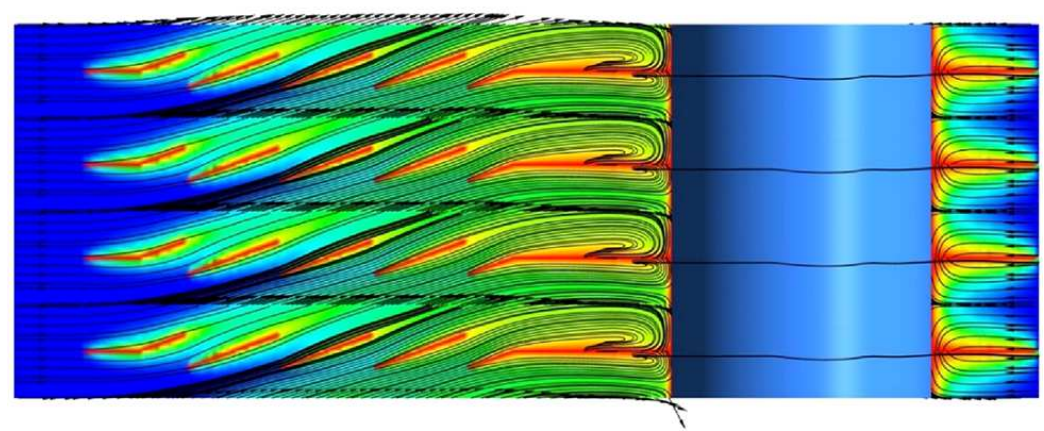

c) Louver angle $20^{\circ}$

FIG. 7: Air flow temperature contours with pathline for louver angles from $0^{\circ}$ to $20^{\circ}$ for four fin rows: (a) louver angle $0^{\circ}$; (b) louver angle $10^{\circ}$; (c) louver angle $20^{\circ}$ 


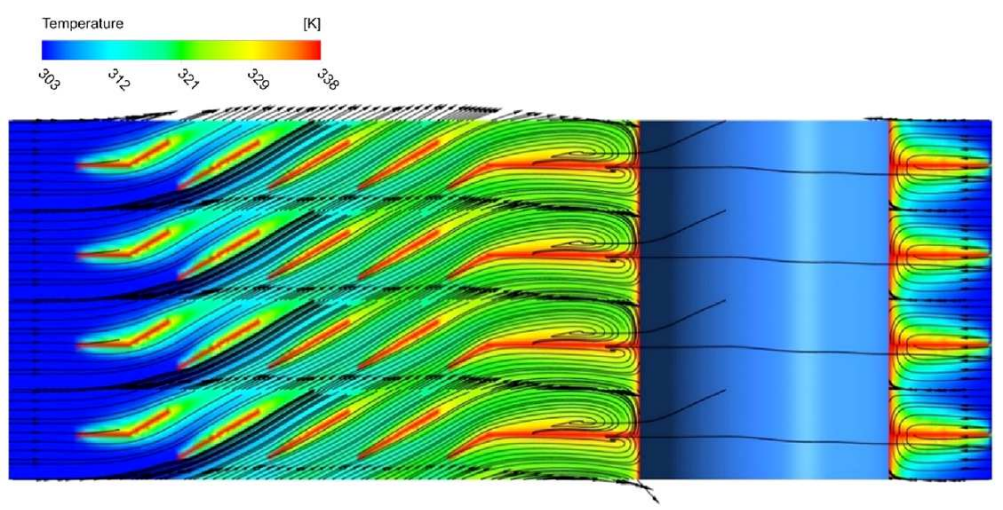

a) Louver angle $30^{\circ}$

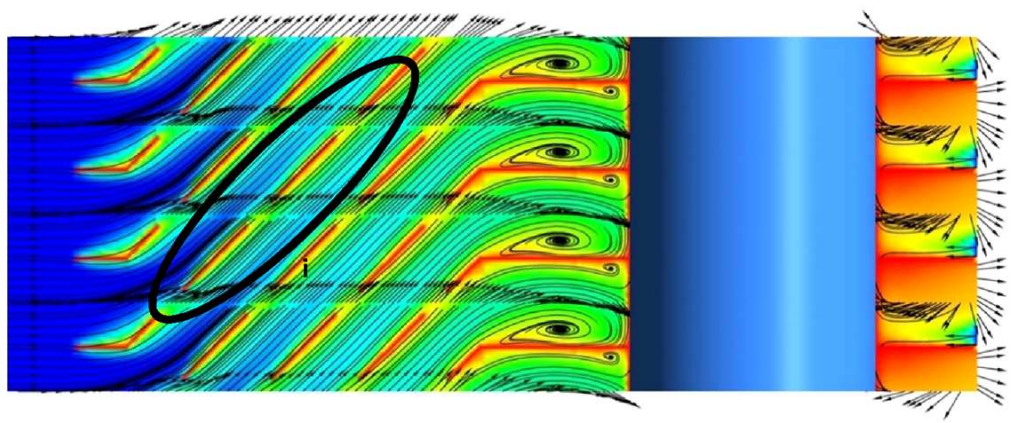

b) Louver angle $45^{\circ}$

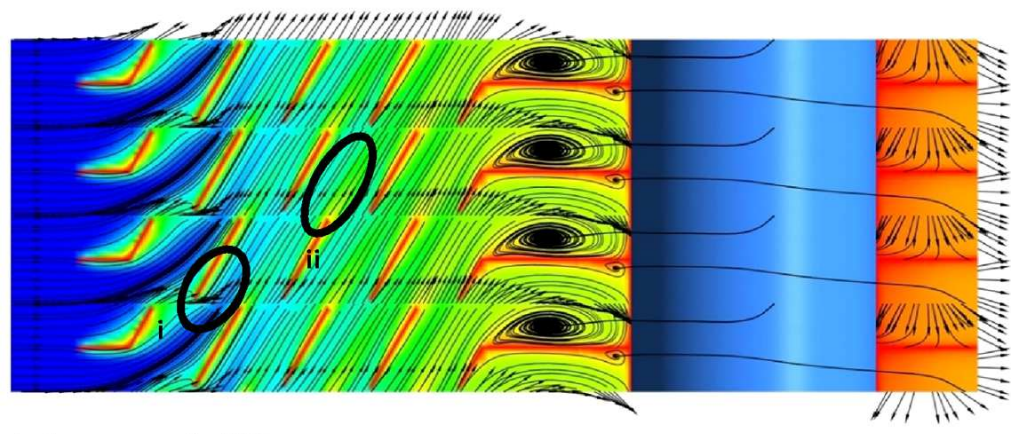

c) Louver angle $60^{\circ}$

FIG. 8: Air flow temperature contours with pathline for louver angles from $30^{\circ}$ to $60^{\circ}$ for four fin rows: (a) louver angle $30^{\circ}$; (b) louver angle $45^{\circ}$; (c) louver angle $60^{\circ}$

to $\theta=60^{\circ}$ at an air inlet velocity of $1 \mathrm{~m} / \mathrm{s}$. It is clear that air flow in zero louver angle (plain fin) is somehow similar to the developing flow between two parallel plates [Fig. 7(a)]. Increasing the louver angle to $10^{\circ}$ [Fig. 7(b)], some airflow is directed by the louver to mingle the airstream of the adjacent channels. However, even though the airflow can flow across the louver to fulfill appreciable mixing when compared with the plain, there is only a small fraction of flow that can go through the louvers, so the penetration of directed airflow is less intense. The results indicate that the flow pattern is more like a channel flow rather than fin directed flow. For louver fin and

Volume 27, Issue 4, 2020 
flat-tube heat exchangers, the flow visualization conducted by Webb and Trauger (1991) concluded that increase of louver angle increases the flow efficiency, which is defined as the actual transverse distance of the airflow divided by the ideal transverse distance of the airflow. Hence, the boundary-layer renewal becomes more pronounced for offering more effective mixing with further rise of louver angle. With the increase in louver angle to $20^{\circ}$ [Fig. 7(c)], the flow pattern is disturbed significantly, and a considerable fraction of flow passes through the louvers and penetrates into more fin channels, suggesting a higher flow efficiency. This change in flow pattern increases heat transfer and consequently the Colburn $j$ factor. In fact, louver angle around $20^{\circ}$ shows the optimum performance for flow patterns from parallel flow to the disturbed flow. The performance peak for a louver angle of $20^{\circ}$ is also reported by Čarija et al. (2014). For louver angle from $20^{\circ}$ to $60^{\circ}$, the alignment of louvers and consequently the alignment of passages between louvers are important. Louvers in different fin rows become more aligned when varying the louver angle from $20^{\circ}$ to $45^{\circ}$ [Fig. 8(a)] where the air flows alongside the louver direction in parallel, and the mixing alongside the louver direction is actually decreasing, which results in a level-off or decreasing trend of Colburn $j$ factor. For a louver angle of $45^{\circ}$ [Fig. 8(b)], the flow goes along louvers after impinging to the first louver and since all louvers are completely aligned, the boundary layer grows and consequently heat transfer and Colburn factor decrease [i in Fig. 8(b)]. For a louver angle of $60^{\circ}$ [Fig. 8(c)], the airflow passes the louver and hits the louver located at the neighboring fin in a staggered manner, forcing the redevelopment of the boundary layer. As a consequence, heat transfer performance is augmented. Yet, the staggered manner of the louvers in the nearby fins also leads to a rise in maximum flow velocity across the louver. Note that some parts of this airflow impinge onto the first louver and incur noticeable flow separation [i in Fig. 8(c)]. This separation causes other parts of flow to flow upward between the second and the third louvers of the second upper fin row. Velocity of flow in this part is much higher while this higher velocity causes more heat transfer and increases the Colburn $j$ factor accordingly [ii in Fig. 8(c)].

In essence, increases in the Colburn $j$ factors when the louver angles exceed $45^{\circ}$ are mainly attributed to the staggered configuration regarding the arrangement of louvers in nearby fins. Small vorticities generated in top of the first half-louver increases the heat transfer slightly while vortices generated between the last louver and tube are increased with the rise of louver angle, which also promotes heat transfer for speeding up the maximum velocity.

\subsection{Effect of Fin Pitch}

To investigate the effects of fin pitch $\left(F_{p}\right)$ on $j$ and $f$ factors of louver fin-and-tube heat exchangers, fin pitch is increased from $2.5 \mathrm{~mm}$ to $5 \mathrm{~mm}$. Longitudinal tube pitch is constant at $15 \mathrm{~mm}$ and louver angle is raised from $\theta=0^{\circ}$ to $\theta=60^{\circ}$. Other geometrical parameters are the same as listed in Table 2. From Fig. 6, an air inlet velocity of $1 \mathrm{~m} / \mathrm{s}$ yields the maximum $j$ and $f$ factors in the range of 1-6.5 m/s. Hence, the examination of the effects of fin pitch on these factors is mainly conducted at an inlet velocity of $1 \mathrm{~m} / \mathrm{s}$. The maximum possible louver angle is limited by the fin pitch. Therefore, the maximum louver angle is less than $60^{\circ}$ in some cases. Figure 9 shows $j$ and $f$ factors vs. louver angle. Similarly, as the influence of louver angle, the results for the Colburn $j$ factor can be categorized into three stages while friction factors are termed with two regions. However, the influence of fin pitch is rather small. This is applicable either for the Colburn $j$ factor or friction factor. The results are in line with the test results for louver fin-andtube heat exchangers without redirection louver by Wang et al. (1998a) and louver fin-and-tube heat exchangers with redirection louver by Wang et al. (1998b). 


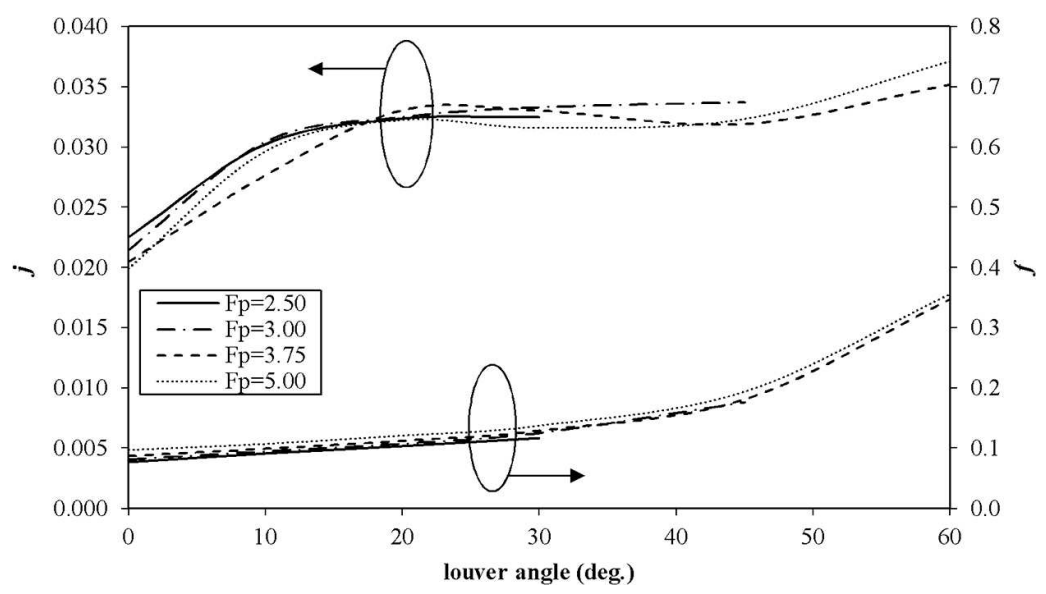

FIG. 9: Effect of $F_{p}$ on $j$ and $f$ factors in different louver angles

\subsection{Effects of Transversal and Longitudinal Tube Pitches}

The effects of transversal $\left(P_{t}\right)$ and longitudinal $\left(P_{l}\right)$ tube pitches on $j$ and $f$ factors of louver fin-and-tube heat exchangers were studied further. For this purpose, the transversal tube pitch was fixed at $25.4 \mathrm{~mm}$ and values of $15 \mathrm{~mm}, 19.05 \mathrm{~mm}$, and $30 \mathrm{~mm}$ were selected as longitudinal tube pitch. The simulations were then followed by changing transversal tube pitch from $25.4 \mathrm{~mm}$ to $40 \mathrm{~mm}$ while fixing longitudinal tube pitch at $19.05 \mathrm{~mm}$. Louver angle was changed from $\theta=$ $0^{\circ}$ to $\theta=60^{\circ}$ and $u_{\text {in }}=1 \mathrm{~m} / \mathrm{s}$, while other geometrical parameters are listed in Table 2. $j$ and $f$ factors in different louver angles for different transversal and longitudinal tube pitches are shown in Figs. 10 and 11, respectively. As seen in the figures, it is clear that raising either longitudinal or transversal tube pitches imposes impact on the Colburn $j$ factor. The first reason for this decline with the increase in either of pitches may impair the fin efficiency and reduce the effective temperature difference between airflow and the fin/wall surfaces. The second reason is decrease of mixing intensity for the hot fluid near the surface and the cold fluid far from the

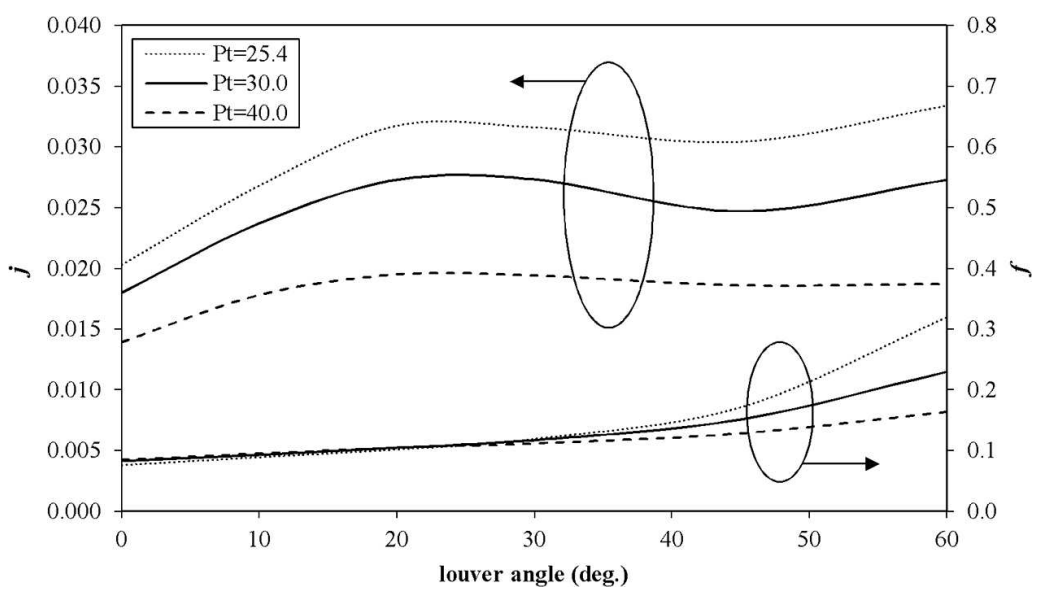

FIG. 10: Effect of $P_{t}$ on $j$ and $f$ factors in different louver angles

Volume 27, Issue 4, 2020 


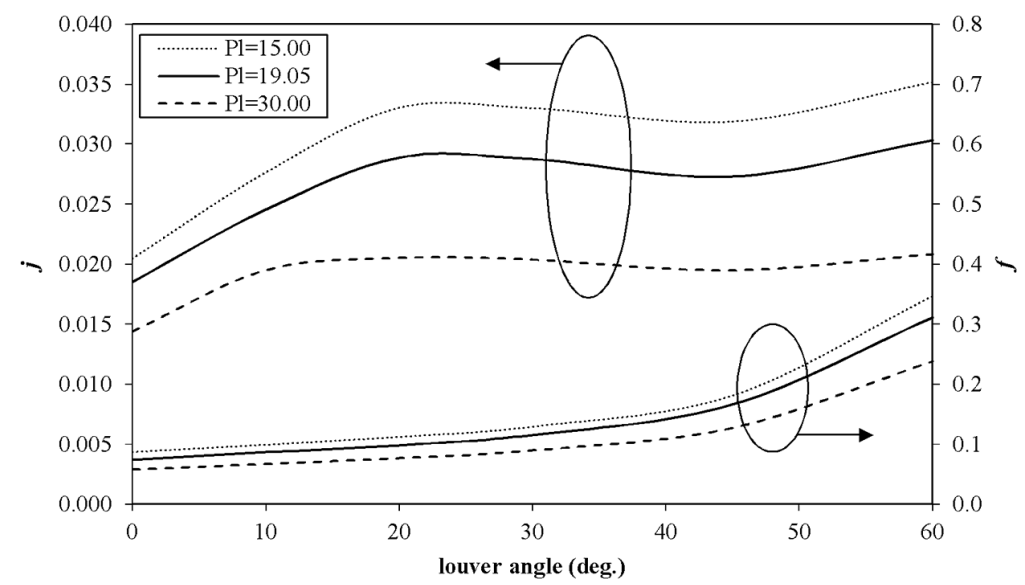

FIG. 11: Effect of $P_{l}$ on $j$ and $f$ factors in different louver angles

surface since louver regions are comparatively distant away from each other. Decrease in $j$ factor from $P_{l}=15 \mathrm{~mm}$ to $P_{l}=30 \mathrm{~mm}$ increases from a louver angle of $0^{\circ}$ (plain fin) to a louver angle of $60^{\circ}$. This phenomenon can also be seen for changing the transversal tube pitch from $P_{t}=25.4 \mathrm{~mm}$ to $P_{t}=40 \mathrm{~mm}$.

For further investigation of the effects of transversal and longitudinal tube pitches on friction factor, pressure contours related to Figs. 10 and 11 for a louver angle of $20^{\circ}$ in the $y=0.3 \mathrm{~mm}$ plane are shown in Fig. 12. As illustrated in Fig. 12(a), with increase in longitudinal tube pitch, the effect of the louvers on friction factor will not change while a decrease of the ratio of the louver area to the nonlouver area of plain fin causes a relatively small decrease in friction factor. Consequently, friction factor decreases with the rise in longitudinal tube pitch.

For different transversal tube pitches, variations of friction factor are very small for louver angles from $0^{\circ}$ to $20^{\circ}$. As mentioned earlier, the effects of louvers are comparatively weak because the major airflow is flowing on the fin channel rather than in the louvers. Friction factor decreases with the increase in transversal tube pitch for louver angles from $20^{\circ}$ to $60^{\circ}$. As shown in Fig. 12(b), when louver angle exceeds $20^{\circ}$, smaller fraction of inlet fluid passes through the louvers with increase in transversal tube pitch. Also, pressure losses upon the tubes are lessened. Consequently, significant decrease in friction factor occurs.

It is clear that the effect of transversal tube pitch $\left(P_{t}\right)$ on friction factor is more pronounced than the effect of longitudinal tube pitch $\left(P_{l}\right)$. The main reason is due to the contraction/expansion between adjacent tubes. Furthermore, two different zones can be seen in $f$ factor for both transversal and longitudinal tube pitches, the same as in Fig. 6.

\section{OPTIMIZATION BY FULL FACTORIAL METHOD}

In the full factorial method, some desirable values should be selected for each parameter and numerical simulations must be performed for all combinations of parameters. So, all parameters participate in the optimization. Based on the parametric studies, fin pitch imposes rather small effects on heat transfer and friction factor. Hence, fin pitch will not be included in the optimization. Transversal tube pitch, longitudinal tube pitch, louver angle, and air inlet velocity are the major parameters the optimizations, and the related parameters for optimization are tabulated in Table 4. 


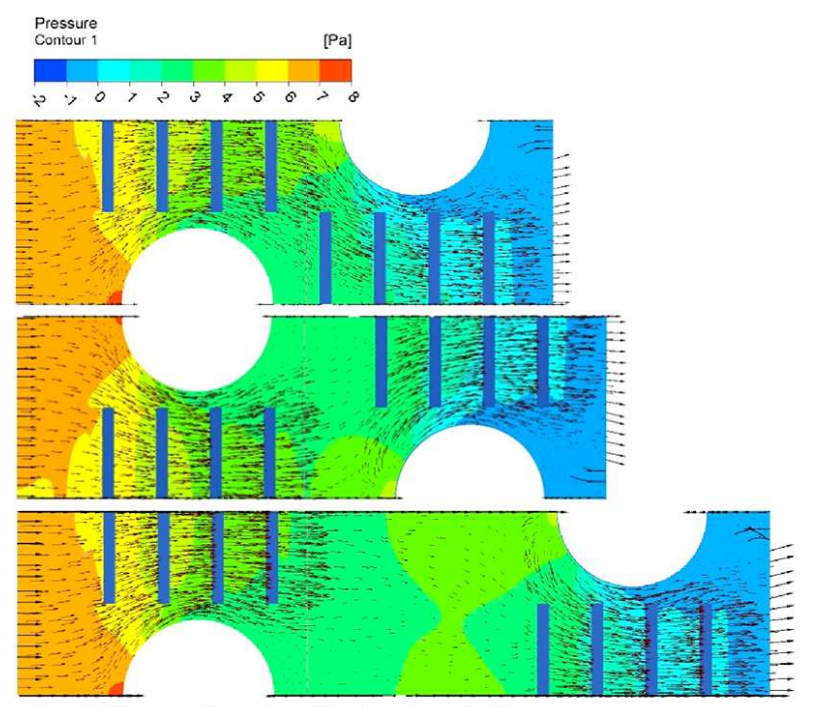

\author{
$P_{l}=15.00 \mathrm{~mm}$ \\ $P_{l}=19.05 \mathrm{~mm}$ \\ $P_{l}=30.00 \mathrm{~mm}$
}

a) Different longitudinal tube pitches

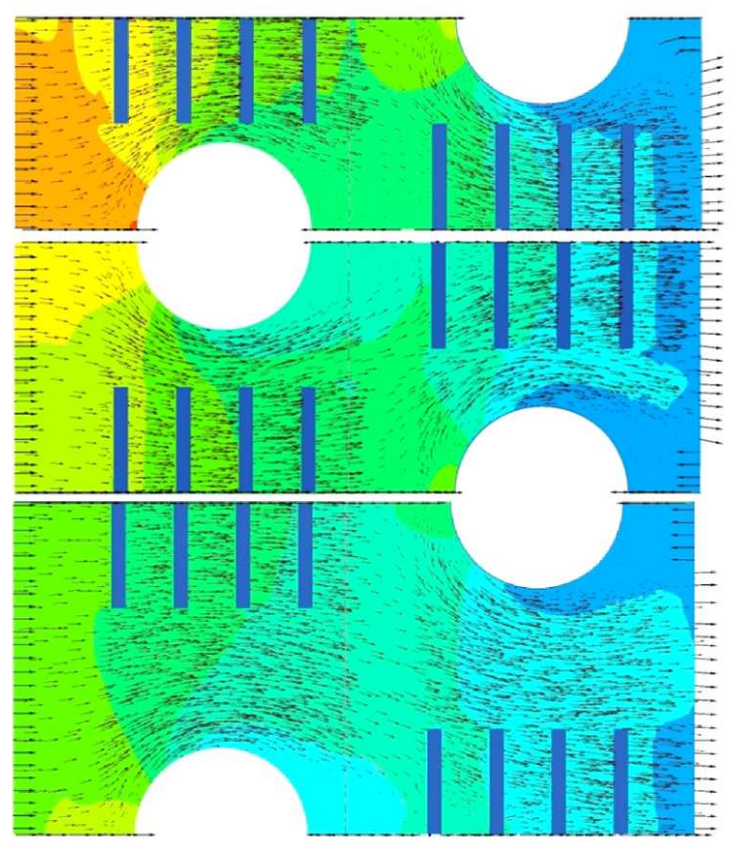

$P_{t}=25.4 \mathrm{~mm}$

$P_{t}=30.0 \mathrm{~mm}$

$P_{t}=40.0 \mathrm{~mm}$

b) Different transversal tube pitches

FIG. 12: Static pressure contours in different (a) longitudinal and (b) transversal tube pitches in louver angle of $20^{\circ}$ in plane of $y=0.3 \mathrm{~mm}$

A total of 112 numerical simulations were performed by combination based on Table 4. Optimizations of $j$ and $f$ factors were carried out using numerical simulation data by full factorial method. The optimum criteria were maximizing Colburn factor while minimizing friction factor whenever possible. The final results for optimization are shown in Fig. 13. This figure consists of

Volume 27, Issue 4, 2020 
TABLE 4: Parameter values used for optimization

\begin{tabular}{|c|c|c|c|c|c|c|c|}
\hline Parameter & \multicolumn{7}{|c|}{ Values used for optimization } \\
\hline Transversal tube pitch $\left(P_{t}\right)(\mathrm{mm})$ & 25.4 & 30 & - & - & - & - & - \\
\hline Longitudinal tube pitch $\left(P_{l}\right)(\mathrm{mm})$ & 15 & 19.05 & - & - & - & - & - \\
\hline Air inlet velocity $(V)(\mathrm{m} / \mathrm{s})$ & 1 & 2 & 4 & 6.5 & - & - & - \\
\hline Louver angle $(\theta)($ deg. $)$ & 0 & 10 & 20 & 30 & 45 & 60 & 80 \\
\hline
\end{tabular}

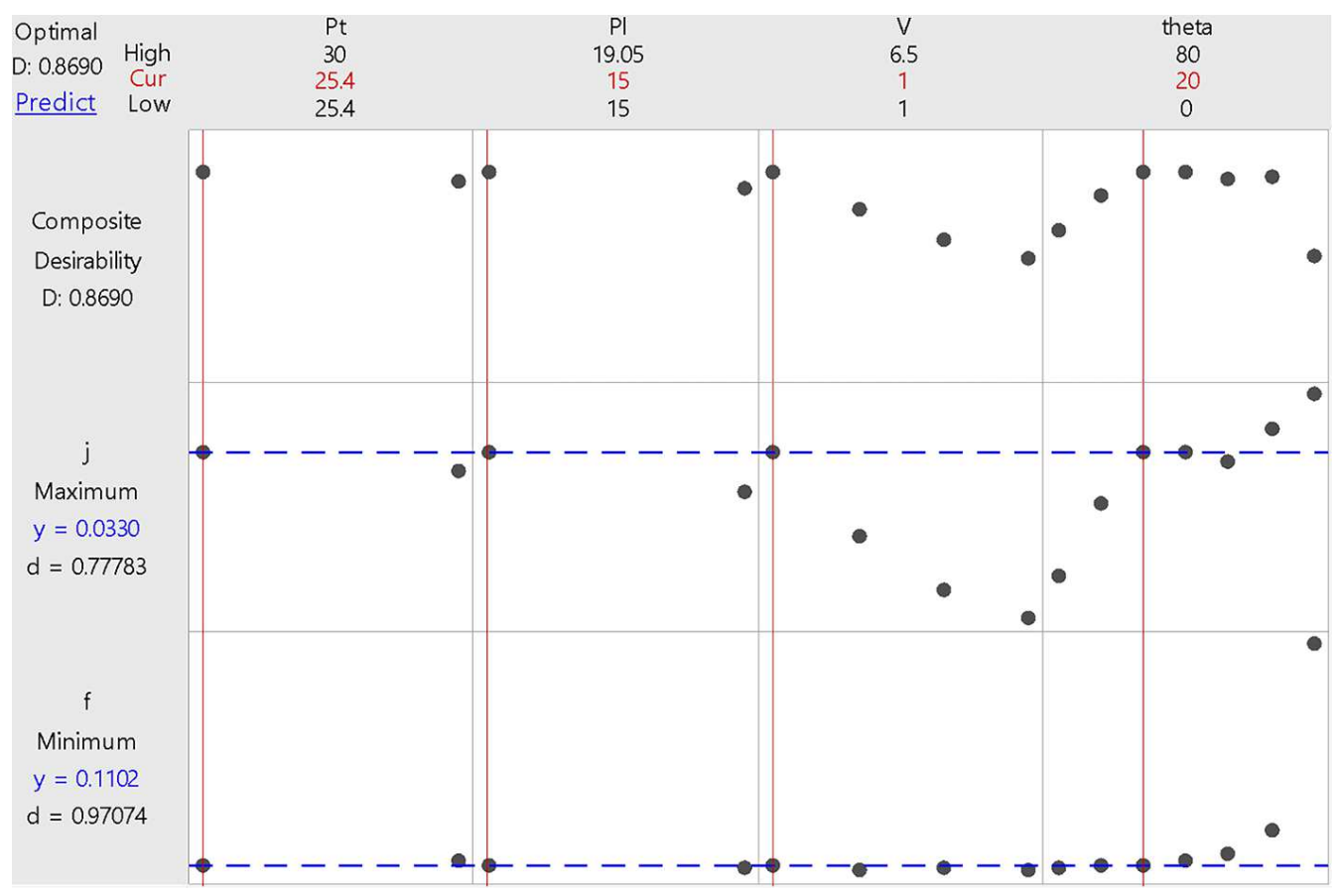

FIG. 13: Results of optimization by full factorial method

four columns and three rows, which are separated by grey lines. Each column is assigned to one of the studied parameters, which is mentioned as the header of that column, while the upper and lower values are shown under each parameter. For optimization purpose, it is essential to attain the maximum Colburn factor and minimum friction factor, simultaneously, which is defined as composite desirability. In this regard, there may be more than one optimum working condition, the degree of optimization can be judged by composite desirability factor. The objective is to approach this factor toward unity as the degree of optimization. The composite desirability of each working point for each parameter (based on Table 4) is shown in the first row while it is related to $j$ and $f$ factors, and the calculated optimal values of other parameters are indicated in the second and third rows, respectively. For example, there are four dots in the velocity column (third column), meaning four values are selected for velocity in the range of 1 to $6.5 \mathrm{~m} / \mathrm{s}$ which is based on Table 4 and the calculated in optimal values of $P_{t}, P_{l}$, and $\theta$.

As shown in the figure, the maximum Colburn factor is 0.0330 and the minimum friction factor is 0.1102 , which are indicated by blue dash lines. Accordingly, the working points are among those candidates where the maximized Colburn factor and the minimized friction factor 
are indicated by vertical solid red lines, and its value is also mentioned in red in the header of each column. Further information regarding the fundamentals of the full factorial method can be found in Cavazzuti (2013).

As mentioned earlier, optimum values for friction factor $(f)$ and Colburn factor $(j)$ are 0.1102 and 0.0330 , respectively, which can be obtained by a transversal tube pitch $\left(P_{t}\right)$ of $25.4 \mathrm{~mm}$, a longitudinal tube pitch $\left(P_{l}\right)$ of $15 \mathrm{~mm}$, an air inlet velocity $(V)$ of $1 \mathrm{~m} / \mathrm{s}$, and a louver angle $(\theta)$ of $20^{\circ}$. The calculated optimum louver angle is in accordance with the optimized louver angle obtained by using the genetic algorithm in Sadeghianjahromi et al. (2018a). Optimization in this paper has been performed using a full factorial method, in which all of the parameters used in parametric study are directly participating in optimization. However, the genetic algorithm, which was used by Sadeghianjahromi et al. (2018a) for optimization, needs an input function and they used the developed correlations based on their parametric study as algorithm input, while their developed correlations have mean deviations of $2.19 \%$ and $7.20 \%$ for $j$ and $f$ factors, respectively, which can cause some errors and deviations in optimization.

\section{CONCLUSIONS}

A detailed parametric study was carried out regarding the fin-and-tube heat exchanger having louver fin configuration. The effects of louver angle, fin pitch, transversal tube pitch, and longitudinal tube pitch on heat transfer performance and friction factor were investigated. Moreover, Colburn and friction factors were optimized using numerical results. All in all, the following conclusions are drawn:

- The Colburn $j$ factor increases linearly with louver angle variation from $0^{\circ}$ to $20^{\circ}$, followed by a level-off or slight decline when the louver angle is less than $45^{\circ}$, and finally the level-off trend of the Colburn $j$ factor is reversed and rising when louver angle exceeds $45^{\circ}$. The slopes of increase or decrease of $j$ factor decrease with increase in Reynolds number.

- Friction factor increases linearly (approximately with slope of $1 \%$ ) with louver angle increase from $\theta=0^{\circ}$ to $\theta=60^{\circ}$. However, louvers act as obstacles against fluid flow when louver angles surpass $60^{\circ}$, thereby causing significant increase in friction factor.

- $j$ and $f$ factors are almost independent of fin pitch in the range from 2.5 to $5 \mathrm{~mm}$ and $\operatorname{Re}_{D_{c}}<2000$.

- $j$ and $f$ factors decrease with an increase in transversal and longitudinal tube pitches. For different transversal tube pitches, variations of friction factor are not so significant for louver angles from $0^{\circ}$ to $20^{\circ}$. The influence of transversal tube pitch on friction factor is more pronounced than that of longitudinal tube pitch, especially when the louver angle exceeds $20^{\circ}$.

- The optimum louver angle for maximizing $j$ and minimizing $f$ is obtained around $20^{\circ}$ by full factorial method.

\section{ACKNOWLEDGMENT}

The authors would like to offer thanks for the financial support from the Ministry of Science and Technology of Taiwan, under contract numbers 108-2811-E-009-539 and 108-2622-E-009-027CC2.

Volume 27, Issue 4, 2020 


\section{REFERENCES}

Achaichia, A. and Cowell, T., Heat Transfer and Pressure Drop Characteristics of Flat Tube and Louvered Plate Fin Surfaces, Exper. Thermal Fluid Sci., vol. 1, pp. 147-157, 1988.

Asadi, M., Sunden, B., and Xie, G., Constructal Optimization of Louver Fin Channels Subjected to Heat Transfer Rate Maximization and Pressure Loss Minimization, Heat Transf. Eng., vol. 39, pp. 436-448, 2018.

Atkinsona, K., Drakulic, R., Heikal, M., and Cowell, T., Two- and Three-Dimensional Numerical Models of Flow and Heat Transfer over Louvred Fin Arrays in Compact Heat Exchangers, Int. J. Heat Mass Transf., vol. 41, pp. 4063-4080, 1998.

Awad, M. and Muzychka, Y.S., Models for Pressure Drop and Heat Transfer in Air Cooled Compact Wavy Fin Heat Exchangers, J. Enhanced Heat Transf., vol. 18, pp. 191-207, 2011.

Baldwin, S., White, P., Al-Daini, A., and Davenport, C., Investigations of the Gas Side Flow Field in Multilouvred Ducts with Flow Reversal, 5th Int. Conf. on Numerical Methods in Laminar and Turbulent Flow, pp. 482-495, 1987.

Čarija, Z., Franković, B., Perčić, M., and Čavrak, M., Heat Transfer Analysis of Fin-and-Tube Heat Exchangers with Flat and Louvered Fin Geometries, Int. J. Refrigeration, vol. 45, pp. 160-167, 2014.

Cavazzuti, M., Optimization Methods: From Theory to Design Scientific and Technological Aspects in Mechanics, Germany: Springer, 2013.

Cowell, T., Heikal, M., and Achaichia, A., Flow and Heat Transfer in Compact Louvered Fin Surfaces, Exper. Thermal Fluid Sci., vol. 10, pp. 192-199, 1995.

Dai, Z., Nawaz, K., Park, Y., Chen, Q., and Jacobi, A., A Comparison of Metal-Foam Heat Exchangers to Compact Multilouver Designs for Air-Side Heat Transfer Applications, Heat Transf. Eng., vol. 33, pp. 21-30, 2012.

Dogan, B., Altun, Ö., Ugurlubilek, N., Tosun, M., Sarıçay, T., and Erbay, L.B., An Experimental Comparison of Two Multi-Louvered Fin Heat Exchangers with Different Numbers of Fin Rows, Appl. Thermal Eng., vol. 91, pp. 270-278, 2015.

Erbay, L.B., Uğurlubilek, N., Altun, Ö., and Doğan, B., Numerical Investigation of the Air-Side Thermal Hydraulic Performance of a Louvered-Fin and Flat-Tube Heat Exchanger at Low Reynolds Numbers, Heat Transf. Eng., vol. 38, pp. 627-640, 2017.

Glazar, V., Trp, A., and Lenic, K., Numerical Study of Heat Transfer and Analysis of Optimal Fin Pitch in a Wavy Fin-and-Tube Heat Exchanger, Heat Transf. Eng., vol. 33, pp. 88-96, 2012.

Han, H., He, Y.L., Li, Y.S., Wang, Y., and Wu, M., A Numerical Study on Compact Enhanced Fin-andTube Heat Exchangers with Oval and Circular Tube Configurations, Int. J. Heat Mass Transf., vol. 65, pp. 686-695, 2013.

Hrnjak, P., Zhang, P., and Rennels, C., Effect of Louver Angle on Performance of Heat Exchanger with Serpentine Fins and Flat Tubes in Frosting: Importance of Experiments in Periodic Frosting, Int. J. Refrigeration, vol. 84, pp. 321-335, 2017.

Hsieh, C.T. and Jang, J.Y., 3D Thermal-Hydraulic Analysis for Louver Fin Heat Exchangers with Variable Louver Angle, Appl. Thermal Eng., vol. 26, pp. 1629-1639, 2006.

Hsieh, C.T. and Jang, J.Y., Parametric Study and Optimization of Louver Finned-Tube Heat Exchangers by Taguchi Method, Appl. Thermal Eng., vol. 42, pp. 101-110, 2012.

Jang, J.Y. and Chen, C.C., Optimization of Louvered-Fin Heat Exchanger with Variable Louver Angles, Appl. Thermal Eng., vol. 91, pp. 138-150, 2015.

Jang, J.Y. and Yang, J.Y., Experimental and 3-D Numerical Analysis of the Thermal-Hydraulic Characteristics of Elliptic Finned-Tube Heat Exchangers, Heat Transf. Eng., vol. 19, pp. 55-67, 1998. 
Javaherdeh, K., Vaisi, A., Moosavi, R., and Esmaeilpour, M., Experimental and Numerical Investigations on Louvered Fin-and-Tube Heat Exchanger with Variable Geometrical Parameters, J. Thermal Sci. Eng. Appl., vol. 9, p. 024501, 2017.

Jiao, A. and Baek, S., Effects of Distributor Configuration on Flow Maldistribution in Plate-Fin Heat Exchangers, Heat Transf. Eng., vol. 26, pp. 19-25, 2005.

Karthik, P., Kumaresan, V., and Velraj, R., Experimental and Parametric Studies of a Louvered Fin and Flat Tube Compact Heat Exchanger Using Computational Fluid Dynamics, Alexandria Eng. J., vol. 54, pp. 905-915, 2015a.

Karthik, P., Liaguat Ali Khan, S.I., Kulasekharan, N., and Velraj, R., Experimental and Numerical Investigation of a Louvered Fin and Elliptical Tube Compact Heat Exchanger, Thermal Sci., vol. 19, pp. 679-692, $2015 b$.

Kays, W. and London, A., Heat Transfer and Flow Friction Characteristics of Some Compact Heat Exchanger Surfaces, Trans. ASME, vol. 72, pp. 1075-1097, 1950.

Kays, W.M. and London, A.L., Compact Heat Exchangers, 3rd ed., New York: McGraw-Hill, 1984.

Kim, M.H. and Bullard, C.W., Air-Side Thermal Hydraulic Performance of Multi-Louvered Fin Aluminum Heat Exchangers, Int. J. Refrigeration, vol. 25, pp. 390-400, 2002.

Kim, N.H. and Cho, H., An Experimental Investigation of the Air-Side Performance of Fin-and-Tube Heat Exchangers Having Slit Fins, J. Enhanced Heat Transf., vol. 22, pp. 67-88, 2015.

Kim, N.H. and Youn, B., Airside Performance of Fin-and-Tube Heat Exchangers Having Sine Wave or Sine Wave-Slit Fins, J. Enhanced Heat Transf., vol. 20, pp. 43-58, 2013.

Leu, J.S., Liu, M.S., Liaw, J.S., and Wang, C.C., A Numerical Investigation of Louvered Fin-and-Tube Heat Exchangers Having Circular and Oval Tube Configurations, Int. J. Heat Mass Transf., vol. 44, pp. 4235-4243, 2001.

Li, W. and Wang, X., Heat Transfer and Pressure Drop Correlations for Compact Heat Exchangers with Multi-Region Louver Fins, Int. J. Heat Mass Transf., vol. 53, pp. 2955-2962, 2010.

Lin, C.N., Liu, Y.W., and Leu, J.S., Heat Transfer and Fluid Flow Analysis for Plate-Fin and Oval Tube Heat Exchangers with Vortex Generators, Heat Transf. Eng., vol. 29, pp. 588-596, 2008.

Malapure, V., Mitra, S.K., and Bhattacharya, A., Numerical Investigation of Fluid Flow and Heat Transfer over Louvered Fins in Compact Heat Exchanger, Int. J. Thermal Sci., vol. 46, pp. 199-211, 2007.

Nemati, H. and Moghimi, M., Numerical Study of Flow over Annular-Finned Tube Heat Exchangers by Different Turbulent Models, CFD Lett., vol. 6, pp. 101-112, 2014.

Nemati, H. and Samivand, S., Simple Correlation to Evaluate Efficiency of Annular Elliptical Fin Circumscribing Circular Tube, Arabian J. Sci. Eng., vol. 39, pp. 9181-9186, 2014.

Okbaz, A., Pınarbaşı, A., Olcay, A.B., and Aksoy, M.H., An Experimental, Computational and Flow Visualization Study on the Air-Side Thermal and Hydraulic Performance of Louvered Fin and Round Tube Heat Exchangers, Int. J. Heat Mass Transf., vol. 121, pp. 153-169, 2018.

Orszag, S.A., Yakhot, V., Flannery, W.S., Boysan, F., Choudhury, D., Maruzewski, J., and Patel, B., Renormalization Group Modeling and Turbulence Simulations, Int. Conf. Near-Wall Turbulent Flows, Tempe, AZ, 1993.

Pauley, L.L. and Hodgson, J.E., Flow Visualization of Convex Louver Fin Arrays to Determine Maximum Heat Transfer Conditions, Exper. Thermal Fluid Sci., vol. 9, pp. 53-60, 1994.

Qian, Z., Wang, Q., Cheng, J., and Deng, J., Simulation Investigation on Inlet Velocity Profile and Configuration Parameters of Louver Fin, Appl. Thermal Eng., vol. 138, pp. 173-182, 2018.

Sadeghianjahromi, A., Kheradmand, S., and Nemati, H., Developed Correlations for Heat Transfer and Flow Friction Characteristics of Louvered Finned Tube Heat Exchangers, Int. J. Thermal Sci., vol. 129, pp. 135-144, 2018a.

Volume 27, Issue 4, 2020 
Sadeghianjahromi, A., Kheradmand, S., Nemati, H., Liaw, J.S., and Wang, C.C., Compound Heat Transfer Enhancement of Wavy Fin-and-Tube Heat Exchangers through Boundary Layer Restarting and Swirled Flow, Energies, vol. 11, p. 1959, 2018 b.

Sadeghianjahromi, A., Kheradmand, S., Nemati, H., and Wang, C.C., Heat Transfer Enhancement of Wavy Fin-and-Tube Heat Exchangers via Innovative Compound Designs, Int. J. Thermal Sci., vol. 149, p. 106211, 2020.

Shah, R.K. and Sekulic, D.P., Fundamentals of Heat Exchanger Design, John Wiley \& Sons, 2003.

Srinivasu, D., Santharao, D., and Ramakrishna, A., CFD Analysis to Predict Heat Transfer Performance of Louver Fin Radiator with Water/Eg and $\mathrm{Al}_{2} \mathrm{O}_{3}$ Nano Fluid, Int. J. Sci. Eng. Adv. Technol., vol. 4, pp. 159-164, 2016.

T'Joen, C., Huisseune, H., Caniére, H., Steeman, H.J., Willockx, A., and De Paepe, M., Interaction between Mean Flow and Thermo-Hydraulic Behaviour in Inclined Louvered Fins, Int. J. Heat Mass Transf., vol. 54, pp. 826-837, 2011a.

T'Joen, C., Huisseune, H., Willockx, A., Caniere, H., and De Paepe, M., Combined Experimental and Numerical Flow Field Study of Inclined Louvered Fins, Heat Transf. Eng., vol. 32, pp. 176-188, 2011 b.

Taler, D., Experimental Determination of Heat Transfer and Friction Correlations for Plate Fin-and-Tube Heat Exchangers, J. Enhanced Heat Transf., vol. 11, pp. 183-204, 2004.

Tao, Y.B., He, Y.-L., Wu, Z.G., and Tao, W.-Q., Numerical Design of an Efficient Wavy Fin Surface based on the Local Heat Transfer Coefficient Study, J. Enhanced Heat Transf., vol. 14, pp. 315-332, 2007.

Vaisi, A., Esmaeilpour, M., and Taherian, H., Experimental Investigation of Geometry Effects on the Performance of a Compact Louvered Heat Exchanger, Appl. Thermal Eng., vol. 31, pp. 3337-3346, 2011.

Wang, C.C., Chang, J.Y., and Chiou, N.F., Effects of Waffle Height on the Air-Side Performance of Wavy Fin-and-Tube Heat Exchangers, Heat Transf. Eng., vol. 20, pp. 45-56, 1999.

Wang, C.C., Chang, Y.J., Hsieh, Y.C., and Lin, Y.T., Sensible Heat and Friction Characteristics of Plate Fin-and-Tube Heat Exchangers Having Plane Fins, Int. J. Refrigeration, vol. 19, pp. 223-230, 1996.

Wang, C.C., Chang, Y.P., Chi, K.Y., and Chang, Y.J., A Study of Non-Redirection Louvre Fin-and-Tube Heat Exchangers, Proc. of the Institution of Mechanical Engineers, Part C: J. Mechan. Eng. Sci., vol. 212, pp. 1-14, 1998a.

Wang, C.C., Chen, K.Y., Liaw, J.S., and Tseng, C.Y., An Experimental Study of the Air-Side Performance of Fin-and-Tube Heat Exchangers Having Plain, Louver, and Semi-Dimple Vortex Generator Configuration, Int. J. Heat Mass Transf., vol. 80, pp. 281-287, 2015.

Wang, C.C., Chi, K.Y., Chang, Y.J., and Chang, Y.P., An Experimental Study of Heat Transfer and Friction Characteristics of Typical Louver Fin-and-Tube Heat Exchangers, Int. J. Heat Mass Transf., vol. 41, pp. 817-822, 1998 b.

Wang, C.C., Tao, W.H., and Du, Y.J., Effect of Waffle Height on the Air-Side Performance of Wavy Finand-Tube Heat Exchangers under Dehumidifying Conditions, Heat Transf. Eng., vol. 21, pp. 17-26, 2000 .

Webb, R.L. and Trauger, P., Flow Structure in the Louvered Fin Heat Exchanger Geometry, Exper. Thermal Fluid Sci., vol. 4, pp. 205-217, 1991. 